\title{
Reelection incentives and political budget cycle: evidence from Brazil*
}

\author{
Fabio Alvim Klein**
}

Summary: 1. Introduction; 2. Literature review; 3. Empirical strategy; 4. Descriptive statistics and tests; 5 . Econometric results; 6 . Conclusions.

Sumário: 1. Introdução; 2. Revisão da literatura; 3. Estratégia empírica; 4. Estatística descritiva e testes; 5 . Resultados econométricos; 6. Conclusões.

KEY WORDs: elections and voting; local public spending; Brazil.

Palavras-chave: eleições e voto; gasto público local; Brasil.

This article tests the presence of political budget cycle (PBC) in municipal elections in Brazil and checks whether mayors who adopt such policy have greater probability of reelection. Based on fiscal and electoral data of 5,406 Brazilian municipalities and applying the difference-in-differences econometric method as well as logistic regressions, the results provide some evidence of $\mathrm{PBC}$ in Brazil, although its magnitude and consistency varies depending on the years used as electoral and non-electoral years. On average, reelectable mayors spend close to $3 \%$ more in election years than nonreelectables. Moreover, reelectables who do run for reelection present a variation in spending which is close to $5 \%$ superior to that of non-reelectables and non-runners. Additionally, the results suggest that mayors who increase public spending during electoral periods have greater chances of being reelected, as long as such spending is done within deficit limits acceptable by voters.

\footnotetext{
* Article received in Nov. 2009 and accepted in Feb. 2010. The author wishes to thank George Avelino (FGV) and Ciro Biderman (FGV) for their valuable contributions. He is also grateful for the comments of Fernanda Machiaveli (Universidade de São Paulo), Gabriela de Brelàz (FGV), Sandro Cabral (Universidade da Bahia) and participants at the Associação Nacional de Pós-Graduação e Pesquisa em Administração (Anpad, 2009) and Associação Nacional dos Centros de Pós-graduação em Economia (Anpec, 2009) meetings.

** Public administration and government doctorate student at São Paulo Business Administration School of Getulio Vargas Foundation (Eaesp/FGV), MSc in economic development from The University of Nottingham, social sciences degree from the Univeristy of São Paulo, public administration degree from Eaesp/FGV. Address: Rua Conde de São Joaquim, 392, ap. 23 - Bela Vista - CEP 01320-010, São Paulo, SP, Brazil. E-mail: faklein@yahoo.com; fabio.klein@gvmail.br.
} 


\begin{abstract}
Incentivos da reeleição e ciclo político-orçamentário: evidência do Brasil
Este artigo testa a presença de ciclo político-orçamentário (CPO) nas eleições municipais no Brasil e checa se prefeitos que adotam tal política têm maiores chances de reeleição. Baseado em dados eleitorais e fiscais de 5.406 municípios brasileiros e aplicando o método econométrico de diferença-em-diferenças e também regressões logísticas, os resultados fornecem alguma evidência de CPO no Brasil, apesar de sua magnitude e consistência variar dependendo dos anos utilizados como anos eleitorais e não eleitorais. Em média, prefeitos reelegíveis gastam em torno de 3\% a mais em anos eleitorais em comparação a prefeitos não reelegíveis. Indo além, reelegíveis que de fato concorrem à reeleição apresentam uma variação no gasto que é quase $5 \%$ superior à variação dos não reelegíveis e não concorrentes. Adicionalmente, os resultados sugerem que prefeitos que aumentam os gastos em anos eleitorais têm maiores chances de reeleição, contanto que tal aumento seja feito dentro de limites de déficit aceitáveis pelos eleitores.
\end{abstract}

\title{
1. Introduction
}

Political budget cycle (PBC) is generally understood as an economic cycle caused by political motivations, and comes in many forms: through the increase in public spending, increase of employment, reduction in taxes, or even through moving spending from less visible public services to more visible ones (Drazen and Eslava, 2004, 2005; Eslava, 2005). Generally, PBC is driven by reelection incentives. One common example is an incumbent politician trying to promote greater economic expansion during electoral periods in order to increase his reelection chances. Therefore, the real (and legal) possibility of an incumbent politician (or party) being reelected is a necessary condition for the concept of political budget cycle to work. In Brazil, the electoral rule allowed reelection of executive posts for the first time in the 1998 national elections. As municipal elections always follow two years later, in 2000 all mayors in Brazil were eligible to run for a second mandate, thus having at principle the same reelection incentives to adopt expansionary policies. Because the electoral rule only allows two subsequent mandates for the same incumbent, in the 2004 elections only part of the mayors were eligible for reelection, since those who were reelected in 2000 could not run for reelection again. This makes the 2004 elections a unique research opportunity for accurately testing the existence of a political budget cycle in the Brazilian municipalities, by allowing us to separate the candidates into two groups: reelectables and nonreelectables, or even further, reelection runners and non-reelectables. With these two groups in hand, which may be called treatment and control groups respectively, it is possible to assess whether the chance to be reelected leads to 
different fiscal incentives during election periods. Based on the very concept of $\mathrm{PBC}$, the original hypothesis to be worked in this study is that reelectable mayors and reelection runners have greater incentives to adopt expansionary policies during election periods than non-reelectable ones.

In most empirical studies on PBC, the dependent variable is a measure of fiscal policy, such as total government spending or expenditures in development projects, while the main independent variable is a dummy reflecting an election period. If a political budget cycle exists, this election dummy should present a positive coefficient on the dependent (fiscal) variable, showing that in electoral periods, there should be an expansionary policy. However, by not addressing the possible differences in the fiscal behaviour of reelectable and non-reelectable incumbents, or between reelection runners and non-reelectables, these studies run the risk of presenting biased estimates due to not clearly distinguishing the effects of a political budget cycle from those of what could be called a natural budget cycle. The difference between these cycles is that in the political cycle, the observed increase in public spending in the last years of a mandate (i.e. electoral periods) should occur purely due to political motivations (i.e. reelection), while in the natural cycle this increase could occur for other non political reasons, like technical difficulties (e.g. transitions in government) ${ }^{1}$ or even legal constraints (e.g. inherited budgets). In the Brazilian case for example, one cannot conclude that any observed increase in spending in the last years of a mandate is evidence of a PBC, since such increase might well be caused by the rules defined in the Lei de Diretrizes Orçamentárias (LDO - Law of Budgetary Guidelines), which states that spending in the first year of a new government is inherited from the last government's approved budget, while the new government can only execute its own budget plan from the second year on. Therefore, the new government would be less inclined to execute the inherited budget plan in its first year, since it would not reflect its own policies, resulting in a period of contraction in public spending. Such rule, associated with the fact that there is an increasing adaptation and learning for the new government to fully implement its policies, makes spending to be naturally increasing throughout the four years of a mandate regardless of political motivations. On the other hand, if there is in fact a political budget

\footnotetext{
${ }^{1}$ As an example, refer to an article published on the newspaper O Estado de S. Paulo, page A4, on 29-12-2008 (www.estadao.com.br), where it showed that new entrants generally have trouble obtaining clear and precise information from the previous government about the city hall's financial and administrative situation, making government transition to be a difficult process.
} 
cycle, then it is expected that spending in the last years of a mandate should grow more for the group of reelectable candidates (and reelection runners) than for the non-reelectable ones, because the very possibility of reelection creates greater incentives for increased spending as election approaches. By comparing the growth rates in spending of these two groups, we are able to disentangle the political budget cycle from the natural budget cycle, and thus correctly estimate the presence and magnitude of a PBC.

Putting it more formally, the hypothesis of a natural budget cycle, as suggested above, tells us that

$$
E\left(g_{i t}-g_{i(t-n)}\right)>0
$$

where $g_{i t}=$ real government spending per capita at municipality $i$ in electoral year $t$, and $g_{i(t-n)}=$ real government spending per capita at municipality $i$ in a non-electoral year $t-n$, while the hypothesis of a political budget cycle tells us that

$$
E\left(\left(g_{i t}^{R}-g_{i(t-n)}^{R}\right)-\left(g_{i t}^{N R}-g_{i(t-n)}^{N}\right)\right)>0
$$

where the upper scripts $R$ and NR correspond to reelectable/reelection runners and non-reelectables respectively.

Equation 1 states that the expected value of the difference in public spending between an electoral year $t$ and a non-electoral year $t-n$ is positive, which is aligned to the notions of a natural budget cycle. Equation 2 goes beyond: it states that the expected value of the difference between the variation in spending of a reelectable mayor (or a runner) and a non-reelectable mayor is positive, meaning that reelectable mayors or runners spend relatively more than non-reelectable mayors in electoral years, which corresponds to the effect of a political budget cycle.

The assumption present in equation 2 could be false if one considers that non-reelectable mayors still have incentives to adopt the PBC strategy, for example if he is aiming at the reelection of his party, election of a party belonging to his coalition, or promoting his own political career whenever running for other posts. These arguments are correct, but suggest that mayors would then equally adopt the same fiscal strategy regardless of their electoral conditions. However, these various situations are difficult to control for in any empirical test. On the other hand, separating mayors into reelectables/runners and non-reelectables is both feasible and meaningful. The assumption of the present study is that such distinction is a sufficient condition for accurately 
testing the existence of a political budget cycle, although it is obviously not the only one.

Taking this approach into account and relying on fiscal and electoral data of 5,406 Brazilian municipalities between 2000 and 2004, this article shows results that seem to confirm the existence of a political budget cycle in Brazil. On average, reelectable mayors spend close to $3 \%$ more in election years than non-reelectables. Moreover, reelectables who do run for reelection present a variation in spending which is close to $5 \%$ superior to that of non-reelectables and non-runners. Worth pointing out is that the evidence varies depending on the years used as non-electoral and electoral years. Additionally, the results indicate that mayors who increase spending during election years increase their chances of reelection. However, these chances decrease if such spending promotes fiscal deficits.

The article is structured as follows. In the next section, a brief literature review on political budget cycle is presented together with explanations of how this study relates to it. In section 3, the empirical strategy is formulated, followed by descriptive statistics in section 4 . The main results are analysed in section 5 , followed by concluding remarks and suggestions for future research in section 6.

\section{Literature review}

The studies on political budget cycles (PBC) belong to a wider literature on political economy where the focus of analysis is on the determinants of fiscal deficits. Part of this analytical body had relied on models of political business cycles. ${ }^{2}$ According to Alesina and Roubini (1992), the models of political cycles are divided into three categories: opportunistic (or electoral); partisan, and rational. On the opportunistic model (Nordhaus, 1975; Lindbeck, 1976), politicians seek to maximise their popularity and reelection chances through expansionary policies during electoral periods, usually followed by contractionary policies after elections. On the partisan model (Hibbs, 1997), the presence of different preferences over policies among the electorate motivates the emergence of different parties to represent these preferences during elections. Thus, the main difference between the electoral and partisan cycles is that in the first, the focus of analysis is on the change in total spending and

\footnotetext{
${ }^{2}$ For a detailed review on PBC, please refer to Franzese and Jusko (2006).
} 
in overall economic indicators, while in the second is on the change in the type of expenditure according to the group of voters a party is aiming at. Finally, the rational models represent a second phase in the political cycle literature, incorporating the concept of rational expectations both to the electoral/opportunistic models (Rogoff and Sibert, 1988; Rogoff, 1990; Persson and Tabellini, 1990) and to the partisan ones (Alesina, 1987), where voters are partially able to learn from past elections and observe governments' performance and thus update their beliefs about any given incumbent's ability. For Rogoff (1990), for example, voters have a preference for high levels of spending, but can observe only part of the public goods produced by the government. As a consequence, incumbents tend to increase the provision of visible public goods such as roads, transport systems, schools and hospitals before elections and reduce spending on other less visible types of goods like debt servicing and personnel payments.

More recent studies add together the rational perspective of the electoral and partisan cycles by assuming voters to be fiscal conservatives, but having preferences for increased spending in some areas, so that politicians and parties seek to satisfy the mix of preferences that maximize their chances of reelection without the need of increasing overall spending and as a consequence incurring in undesirable fiscal deficits (Drazen and Eslava, 2004, 2005; Eslava, 2005). According to this perspective, PBC can take place by a change in the composition of spending while total spending is unchanged (Drazen and Eslava, 2005), a view that has found some empirical support. In Brender (2003) for example, results show that voters in Israel punish high deficits in electoral years, but reward high expenditure in development projects in preelectoral years. In their study on Colombian municipal elections, Drazen and Eslava (2005) find that there is usually a change in the types of expenditures in pre-electoral years, reflected in a reduction of spending in debt services and current expenses (such as payments to temporary personnel and transfers to retired workers) and an increase in investment expenditures (like roads, sewerage and electricity). Moreover, they show that parties which adopt such strategy have greater chances of being reconducted to government.

The present study only takes into account the opportunistic/electoral cycle perspective, without focusing on the partisan cycle, since the unit of analysis here is the reelection of mayors, and not the parties', and because the effect of a political cycle, if there is one, will be checked via variations in total spending, and not variations in the type of spending. The advantage of analysing the reelection of mayors is the possibility of comparing differences in the fiscal behaviour of two groups of mayors, reelectables (or reelection runners) 
and non-reelectables. Such group distinction does not apply to parties, since they can be reelected indefinitely and thus have, at principle and holding other things constant, the same incentives to increase total spending during elections to enhance their reelection chances. ${ }^{3}$ Regarding the decision to focus on total spending rather than on the type of spending, this article is surely losing part of the analysis of political cycles, as correctly pointed by Drazen and Eslava $(2004,2005)$ and Eslava (2005). Even so, it is still an important step to first check whether there is a political budget cycle via total spending in Brazil, not only because there are hardly any studies that have done that, but also because Brazil has recently implemented the Lei de Responsabilidade Fiscal (LRF - Law of Fiscal Responsibility) in 2000, which among other things restricted the capacity of municipalities of incurring in high and continuous deficits. The focus is not on doing a before-after analysis of the political budget cycle and the LRF, but rather to check if a political budget cycle via total spending still exists even after the LRF has been implemented.

\section{Empirical strategy}

A more general formulation of the political budget cycle hypothesis defined in (2) is

$$
E\left(\left(g_{i t}^{T}-g_{i(t-n)}^{T}\right)-\left(g_{i t}^{C}-g_{i(t-n)}^{C}\right)\right)>0
$$

where the upper scripts $T$ and $C$ correspond to the treatment and control groups respectively. Equation 3 states that on average, the difference in real government spending per capita within the treatment group is greater than the difference in real government spending per capita within the control group.

Equation 3 can be estimated through the difference-in-differences (DD) econometric method, which allows us to identify behavioural differences between the treatment and control groups over two distinct periods. For the present study, three different classifications for the treatment and control groups are used: (i) reelectables vs. non-reelectables; (ii) reelection runners vs. non-

\footnotetext{
${ }^{3}$ Naturally, parties can differentiate themselves not by spending more, but by defining the mix of policies that is best aligned with their ideology and political strategy. Therefore, the "type of expenditure" approach is perhaps more adequate than the "total spending" approach whenever one is focusing on partisan cycles.
} 
reelectables; (iii) reelection runners vs. non-runners. Each of these three pairs is observed in two moments in time: period 1 (the "before" period, associated with the non-electoral years 1 and 2 of a mandate, hereby corresponding to 2001 and 2002) and period 2 (the "after" period, associated with electoral years 3 and 4 of a mandate, hereby corresponding to 2003 and 2004).

As explained in Lee (2005), the DD effect can be estimated according to the following linear equation: ${ }^{4}$

$$
\ln g_{i t}=\beta_{0}+\beta_{y} r_{i}+\beta_{t} \tau_{t}+\beta_{d} r_{i} \tau_{t}+b_{x}^{\prime} X_{i t}+b_{d x}^{\prime} r_{i} \tau_{t} X_{i t}+u_{i t}
$$

where $g_{i t}=$ real government spending per capita at municipality $i$ in year $t$, with $t=\{2001,2002,2003,2004\} .^{5}$

The second term $r_{i}$ is the "region" dummy, corresponding to an attribute of observation $i$, where $r_{i}=1$ if the mayor is either reelectable (case $i$ ) or a reelection runner (cases $\mathrm{ii}$ and $\mathrm{iii}$ ), and 0 otherwise.

The third term $\tau_{t}$ is the time dummy, where $\tau_{t}=1$ if $t=2004$ (or 2003) and 0 otherwise. Although 2004 is in fact the electoral year in the present study, additionally testing the pre-electoral year 2003 is justified on both theoretical and practical grounds. As suggested by Rogoff and Sibert (1988), politically motivated expenditures can already occur in pre-electoral years, since part of the public good they generate become visible by voters only after some time. Besides, there are some restrictions imposed by the Brazilian electoral legislation that prohibit some types of expenditures six months before the elections, which are held in October. Therefore, it is expected that politicians anticipate such reactions and restrictions and start a political budget cycle already in 2003.

The fourth term combines the second and third terms and identifies the DD effect as given by (3) through the treatment or control dummy $d$, where

\footnotetext{
${ }^{4}$ For detailed explanations of how the DD method can be modelled as a linear regression similar to 4 , please refer to Lee (2005). An alternative way to test 3 is by applying a simple OLS in a cross-sectional data, provided the dependent variable is constructed as the change in spending between an electoral and a non-electoral year $\left(y_{i t}=g_{i t} / g_{i(t-n)}\right)$ and the main explanatory variable is a dummy which equals 1 for the treatment group and 0 for the control group (e.g. reelectable or not). The results using OLS in a cross-sectional data are not reported here, but they are very similar to the DD results. Another alternative is running a panel data regression using GLS random-effects, which seem to provide statistically stronger but still similar results.

${ }^{5}$ In the regressions, an alternative formulation will use the spending to revenues ratio as the dependent variable $\left(y_{i t}=g_{i t} / r_{i t}\right)$, where $r_{i t}$ is real government revenue per capita. This ratio will be used as a measure of the degree of fiscal deficit. By this measure, zero fiscal deficit is given by $g_{i t} / r_{i t} \leq 1$.
} 
$d=r_{i} \tau_{t}$. Therefore, a treated mayor is one where $d=1$, while a non-treated one satisfies the condition $d=0$. In other words, a treated mayor is one who is reelectable $\left(r_{i}=1\right)$ and observed in an electoral year $\left(\tau_{t}=1\right)$. Under the assumption that the above linear model has external validity, the treatment effect is identified by $\beta_{d}$. According to (3), it is expected that $\beta_{d}>0$ : a mayor who is reelectable or is running for reelection would increase public spending during electoral years more than one who is not eligible for reelection or is eligible but is not running for reelection.

The set $X$ is a set of control variables accounting for other political determinants of public spending, which are further interacted with the treatment. The control variables are: (i) the share of votes obtained by the mayor's party in the previous election (year 2000 elections); ${ }^{6}$ (ii) the party dummies indicating whether the mayor's party is the same as the former (prior to 2002) or the current (after 2002) governor's and/or the president's; and finally (iii) the log of population. The reason for including the share of votes is to have a proxy for the parties' local political strength. The idea is that the higher are these shares in previous elections, the more competitive is the party locally, which would reduce the mayor's need of using the political budget cycle strategy to increase his reelection chances. Thus, it is expected that $\beta_{d x}<0$ for votes share. ${ }^{7}$ As for the party dummies, it could be that mayors whose parties belong to the support group of the state and/or federal government receive more transfers, especially during electoral periods. This "party effect" could be intensified or diminished depending on whether the mayor is running for reelection and on his chances of being reelected. If such favouring occurs, it could be that $\beta_{d x}>0$ for the party dummies whenever the mayor who is reelectable or is running for reelection belongs to the governor's and/or the president's party. Finally, the inclusion of the log of population is used to account for the degree of accountability by voters. Part of the political science literature suggests that the degree of accountability is inversely proportional to the size of the electoral district. The idea is that smaller districts reduce the distance between voters and representatives, which facilitates the flow of information and thus improve accountability. Besides, the weight of each single vote, given by $1 / N$, where $N=$ number of voters, is higher in smaller districts (Porto and Porto, 2000). Given these two facts,

\footnotetext{
${ }^{6}$ The share of votes of the 1996 elections were initially considered, but subsequently removed as they were available for only half of the sample.

${ }^{7}$ This is true if it is assumed that past performance is a proxy for current political strength. But if voters have a negative assessment of the party's current performance, the mayor may either increase spending in an electoral year as a way to reverse its low popularity or give up doing so if his chance of reelection is low. Thus, it could be that $\beta_{x}$ is statistically insignificant for votes share.
} 
voters in smaller districts should be more sensitive to the mayor's performance and should be more capable of clearly identifying the responsible for the success or failure of any given policy. ${ }^{8}$ Therefore, it is expected that $\beta_{d x}<0$ for the $\log$ of population, since the adoption of the political budget cycle strategy should become less effective as the size of districts increase.

In order to apply equation 4 in the regressions, the data was set as a panel data.

In addition to testing whether a political budget cycle takes place in the Brazilian municipal elections, a second and crucial test is to check if mayors who adopt the PBC have greater chances of being reelected. To answer this question, the following logistic model is used:

$$
P(\text { reelected } 2004=1 \Delta g, x)=F\left(\beta_{0}+\beta_{g} \Delta g+\beta_{x}^{\prime} X\right)
$$

where $0<\mathrm{F}(z) /[1+\exp (z)], 0<F(z)<1$, and $\Delta g=g_{i t} / g_{i(t-n)}$

Equation 5 states that the probability of a mayor being reelected in the 2004 elections is, among other things, a function of the variation in real government spending per capita $(\Delta g)$ between an electoral year $t$ and a non-electoral year $t-n$. If the political budget cycle strategy exists and is effective, it is expected that $\beta_{g}>0$, since mayors who had spent relatively more during an electoral year would have had greater chances of being reelected than those who had spent relatively less.

The control variables included in the $X$ set are the same ones as in (4) plus two others: (i) the variation in per capita revenues $\left(r_{i t} / r_{i(t-n)}\right)$ for the same period as in $\Delta g$; and (ii) a measure of fiscal deficit, given by the spending to revenues per capita ratio $\left(g_{i t} / r_{i t}\right)$ for 2004 and 2003. The inclusion of the variation in per capita revenues provides a way to check if revenues themselves affect the chances of reelection, regardless of how and if they are in fact spent. Assuming that voters reward an incumbent only when they have visibility over the public policy, it is expected that $\beta_{x}=0$ for $r_{i t} / r_{i(t-n)}$ if $g_{i t} / g_{i(t-n)}$ is accounted for in the regression. The inclusion of a measure of deficit is important to check whether there is a limit to the adoption of the political budget cycle strategy or not. Assuming that voters are, for some reason, fiscal conservatives, it is expected that $\beta_{x}<0$ for $g_{i t} / r_{i t}$, since mayors who spend more than the available funds would promote deficits that could hurt their image and lower their reelection chances.

\footnotetext{
${ }^{8}$ This has become known in the literature as "clarity of responsibility".
} 


\section{Descriptive statistics and tests}

The data used for this study were taken from the Tribunal Superior Eleitoral (TSE - Higher Electoral Court) and from the Secretaria do Tesouro Nacional (STN - National Treasury Secretary). The creation of the dummy variables reel (reelectables vs. non-reelectables), run04 (reelection runners vs. non-runners) and reel04 (reelected in 2004 vs. not reelected) was based on the results of the municipal elections of 1996, 2000 and 2004. With these results, it was possible to apply the correct treatment for the 2004 elections ("reelectable or not", "ran or not" and "reelected or not") for the current mayor (20012004 mandate). Information related to government spending and revenues had their nominal values adjusted for the accumulated inflation between 2000 (base-year) and the following years (2001-2004) using the IPCA inflation index (Wholesale Consumer Price Index), obtained from the Instituto de Pesquisa Econômica Aplicada (Ipea - Institute of Applied Economic Research). The sample consists of 5,406 Brazilian municipalities, which corresponds to more than $95 \%$ of the whole population.

Descriptive statistics are shown in tables 1 through 4 . Table 1 refers to the whole sample. Comparing variations in spending (varg) and variations in revenues (varrev), it can be seen that spending grew 4 percentage points more than revenues between 2003 and 2001, and it fell 2 percentage points less than revenues between 2003 and 2002, possibly as a result of the increase in both revenues and spending in 2002, followed by a contraction in 2003. The peak in 2002 followed by a fall in 2003 is possibly a reflection of a political budget cycle that took place at the state and federal levels during the 2002 national elections, which will be discussed later. Looking at variations in spending only (varg), we see that there is usually an increase in real spending between an electoral and a non-electoral year, except again for varg32 (variation in real government spending per capita between years 2003 and 2002)..$^{9}$ As discussed in the introduction, this is not necessarily an indication of an electoral cycle, since this increase may well reflect the characteristics of the Brazilian budget cycle, or even because of unobserved economic variables.

\footnotetext{
${ }^{9}$ Although the variation in spending between 2004 and 2003 is reported on the tables, little emphasis will be given for this period, since for the purposes of this paper, both 2003 and 2004 are considered electoral years. The same reasoning applies to the change between 2001 and 2002, not reported here, where both are non-electoral years.
} 
Table 1

\section{Descriptive statistics - whole sample}

\begin{tabular}{|lccccc|}
\hline & \multicolumn{5}{c|}{ Whole sample $(\mathbf{n}=5,406)$} \\
\cline { 2 - 6 } Variable & Obs & Mean & Std. dev. & Min & Max \\
\hline g2001 & 5,391 & $\mathrm{R} \$ 545$ & $\mathrm{R} \$ 296$ & $\mathrm{R} \$ 31$ & $\mathrm{R} \$ 4,392$ \\
g2002 & 5,293 & $\mathrm{R} \$ 587$ & $\mathrm{R} \$ 318$ & $\mathrm{R} \$ 100$ & $\mathrm{R} \$ 5,210$ \\
g2003 & 5,341 & $\mathrm{R} \$ 569$ & $\mathrm{R} \$ 336$ & $\mathrm{R} \$ 102$ & $\mathrm{R} \$ 6,332$ \\
g2004 & 5,270 & $\mathrm{R} \$ 600$ & $\mathrm{R} \$ 352$ & $\mathrm{R} \$ 84$ & $\mathrm{R} \$ 5,785$ \\
r2001 & 5,391 & $\mathrm{R} \$ 562$ & $\mathrm{R} \$ 315$ & $\mathrm{R} \$ 31$ & $\mathrm{R} \$ 4,657$ \\
r2002 & 5,293 & $\mathrm{R} \$ 595$ & $\mathrm{R} \$ 331$ & $\mathrm{R} \$ 100$ & $\mathrm{R} \$ 5,458$ \\
r2003 & 5,341 & $\mathrm{R} \$ 564$ & $\mathrm{R} \$ 336$ & $\mathrm{R} \$ 87$ & $\mathrm{R} \$ 6,224$ \\
r2004 & 5,270 & $\mathrm{R} \$ 614$ & $\mathrm{R} \$ 354$ & $\mathrm{R} \$ 71$ & $\mathrm{R} \$ 5,756$ \\
varg41 & 5,190 & $11 \%$ & $24 \%$ & $-64 \%$ & $943 \%$ \\
varg42 & 5,108 & $2 \%$ & $17 \%$ & $-71 \%$ & $304 \%$ \\
varg43 & 5,185 & $5 \%$ & $14 \%$ & $-67 \%$ & $243 \%$ \\
varg31 & 5,259 & $5 \%$ & $19 \%$ & $-72 \%$ & $660 \%$ \\
varg32 & 5,180 & $-3 \%$ & $13 \%$ & $-75 \%$ & $274 \%$ \\
varrev41 & 5,190 & $10 \%$ & $23 \%$ & $-54 \%$ & $956 \%$ \\
varrev42 & 5,108 & $3 \%$ & $16 \%$ & $-67 \%$ & $309 \%$ \\
varrev43 & 5,185 & $9 \%$ & $13 \%$ & $-57 \%$ & $254 \%$ \\
varrev31 & 5,259 & $1 \%$ & $17 \%$ & $-66 \%$ & $639 \%$ \\
varrev32 & 5,180 & $-5 \%$ & $13 \%$ & $-72 \%$ & $294 \%$ \\
pop2001 & 5,391 & 30,966 & 188,211 & 800 & $10,500,000$ \\
pop2002 & 5,293 & 31,487 & 191,641 & 804 & $10,600,000$ \\
pop2003 & 5,341 & 31,962 & 192,792 & 809 & $10,700,000$ \\
pop2004 & 5,270 & 33,057 & 197,798 & 818 & $10,800,000$ \\
g/r2001 & 5,391 & 0.98 & 0.07 & 0.50 & 1.46 \\
g/r2002 & 5,293 & 0.99 & 0.07 & 0.53 & 1.48 \\
g/r2003 & 5,341 & 1.01 & 0.07 & 0.54 & 1.46 \\
g/r2004 & 5,270 & 0.98 & 0.07 & 0.53 & 1.49 \\
vote2000 & 5,406 & $56 \%$ & $12 \%$ & $24 \%$ & $100 \%$ \\
\hline & & & & & \\
\hline
\end{tabular}

Tables 2 through 4 attempt to disentangle the effects of a political budget cycle (equation 2) from those of a natural budget cycle (equation 1 ) by splitting the sample into treatment and control groups. Looking at the means from table 2 , we see that reelectables present a greater variation in spending than non-reelectables between years 2004 and 2001, and 2003 and 2001, although they also have greater variation in revenues for these same periods, indicating a possible difference in their fiscal administration capacity and effort. These differences are not as strong in other periods, especially considering 2004 and 2002, which 
goes against our expectations. But again, it is important to note that 2002 is also an electoral year in Brazil for state governors, senators, federal deputies and the president, which may generate a political budget cycle in the state and federal levels, possibly and partially explaining the average increase in spending and revenues in 2002 (for example via an increase in state and federal transfers to the municipalities), followed by a reduction in 2003 (see table 1). From table 3 , we see an interesting finding: reelection runners have lower per capita spending and revenues for the non-electoral years 2001 and 2002 when compared to non-reelectables, but have higher figures for the electoral years 2003 and 2004, which seems to confirm the hypothesis that they spend (and collect) more during election years than non-reelectables. Table 4 is a sub sample of the group of reelectables, and compares reelection runners and non-runners. Note that out of the 3,526 reelectable mayors, only 2,243 (63.6\%) chose to run for reelection. This table functions somewhat as the counterfactual evidence against the plausible argument that higher variations in spending and/or revenues between 2004 and 2001, or 2003 and 2001, for the reelectables and reelection runners occurs not because they spend more in the electoral years (2003 and 2004), but because they spend less in the first year (2001), since reelectables are new entrants in 2001, while non-reelectables are the mayors who were reelected in 2000. As discussed in the Introduction, new entrants may face technical difficulties and legal restrictions that make their spending in the first year to be usually lower than the spending of reelected politicians. Thus, even if their spending in 2003 and 2004 were equal to that of non-reelectables, their difference between 2003 and 2001 or 2004 and 2001 would still be higher. This hypothesis is rejected when we compare reelection runners and non-runners as in table 4, because both are reelectables (new entrants), so they should present similar figures for 2001. From table 4, we see that reelection runners not only have greater or at least equal variation in spending and revenues, but also present greater absolute spending and revenues per capita in each year. As for their deficit ratio, note that these are equal to or lower to that of non-runners for 2001 and 2002, but they are slightly higher for 2003 and 2004, showing that runners spend, on average, above their available revenues during electoral years more than non-runners do. In overall terms though, the tables suggest that the deficit ratios of reelectables and reelection runners are usually equal to or lower than those of non-reelectables and non-runners, with only a few exceptions. This provides an indication that reelectables and reelection runners have stronger incentives for keeping public finances under control, probably due to the electoral risks caused by fiscal deficits. Besides, this may be an indirect evidence of the effectiveness of the LRF, implemented in 2000, which probably reduced the level of opportunistic spending, especially for those seeking reelection. 


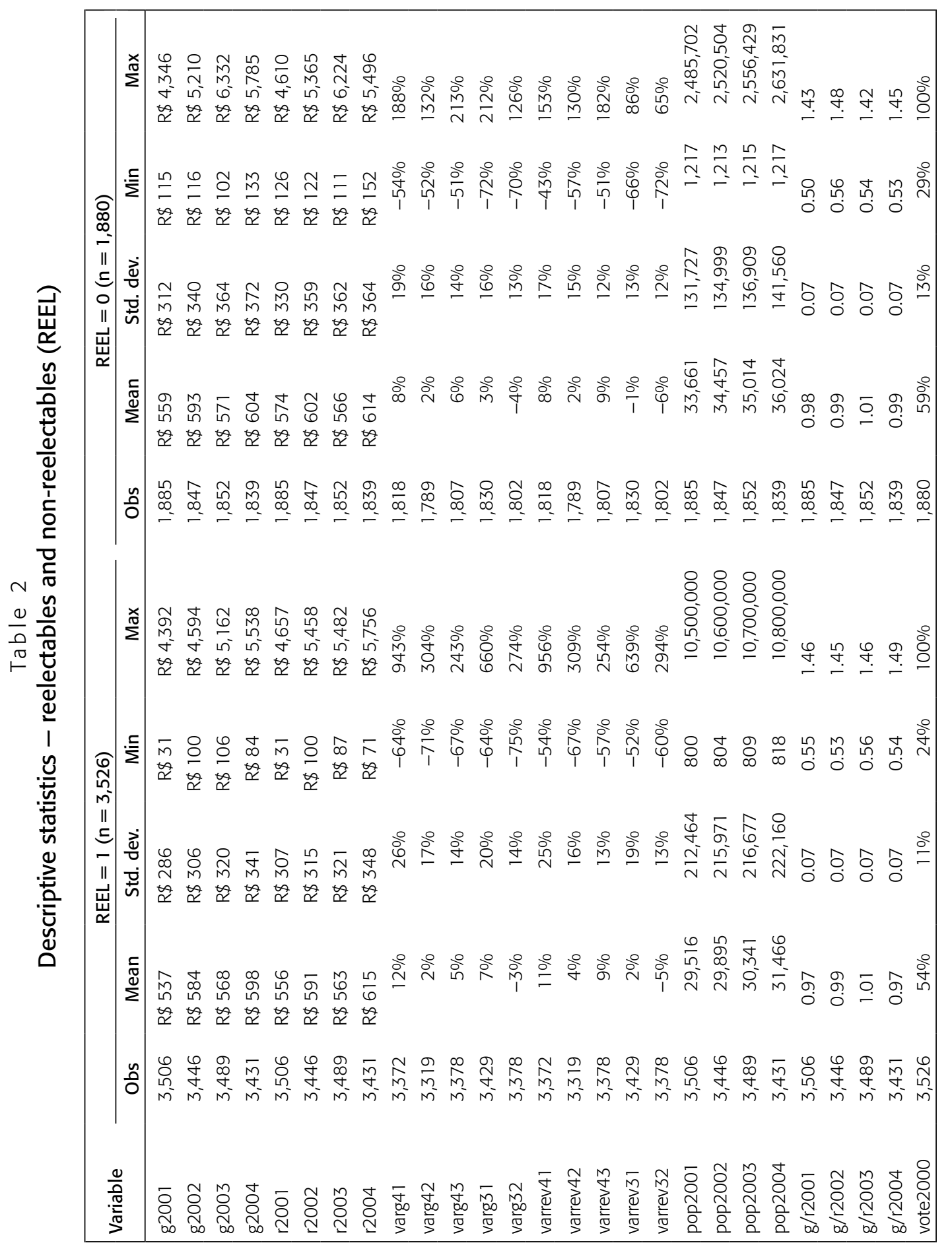




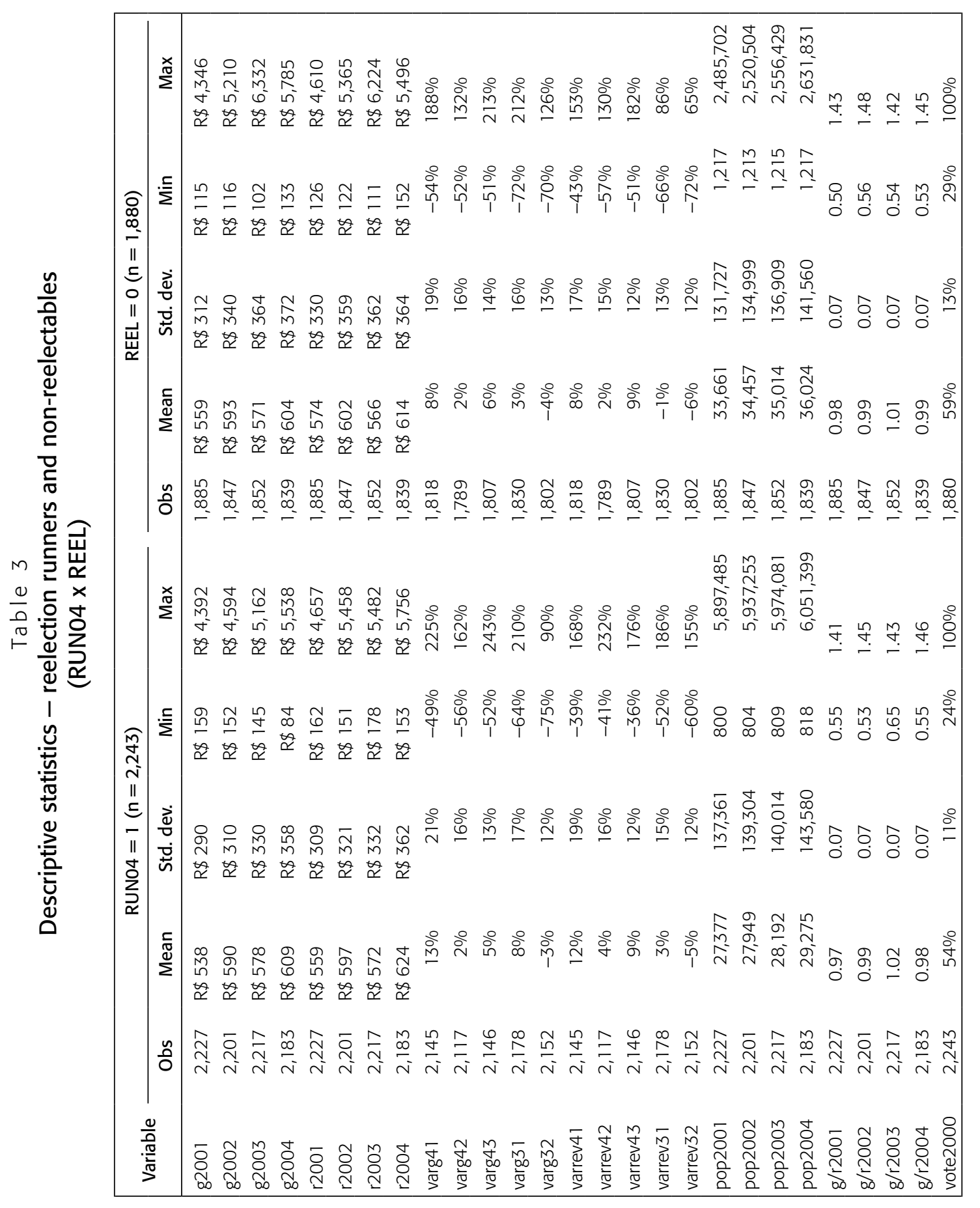




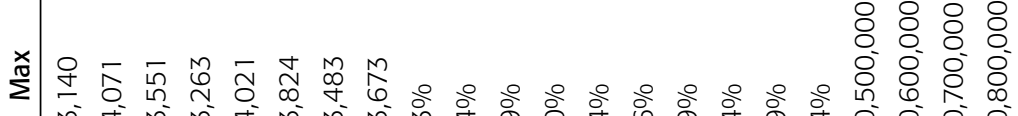

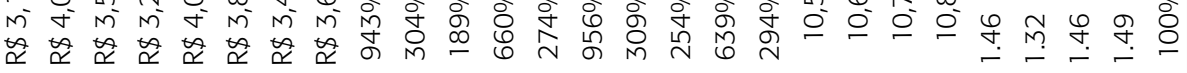

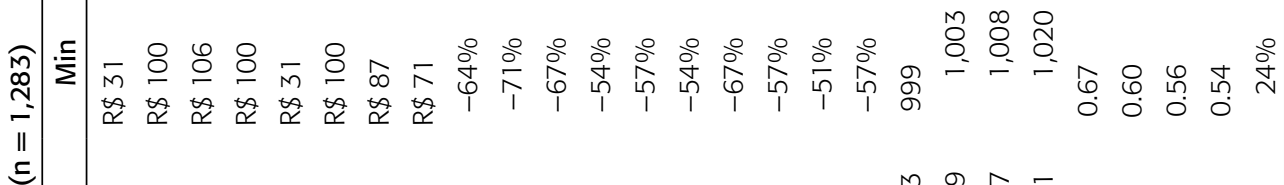

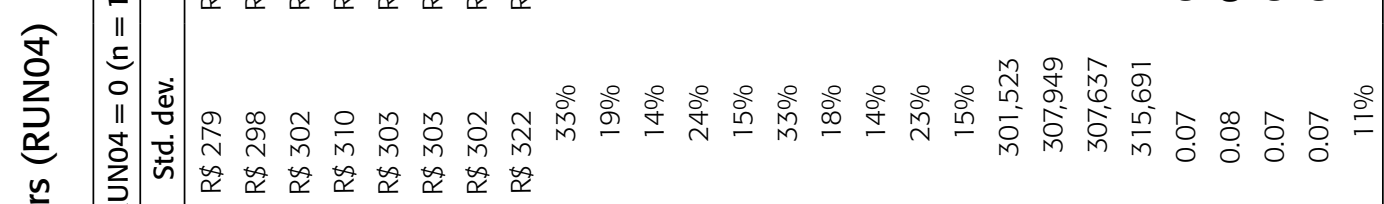

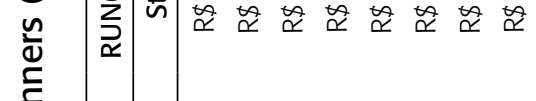

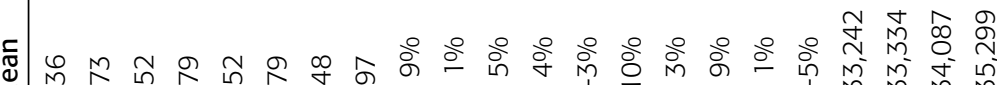

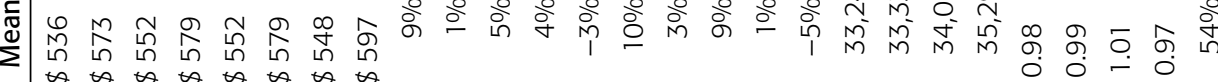

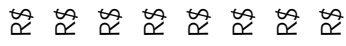

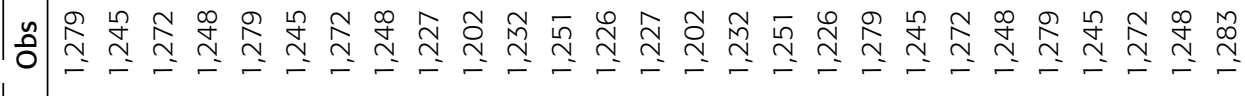

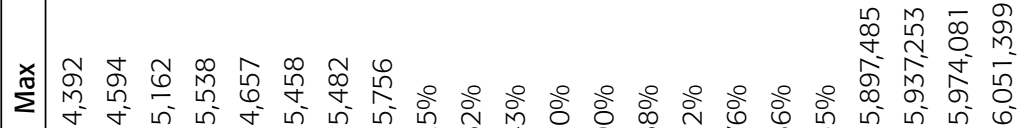

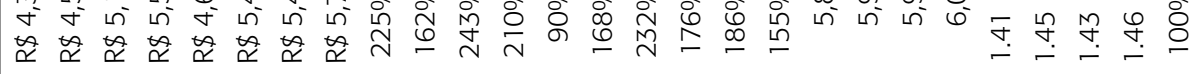

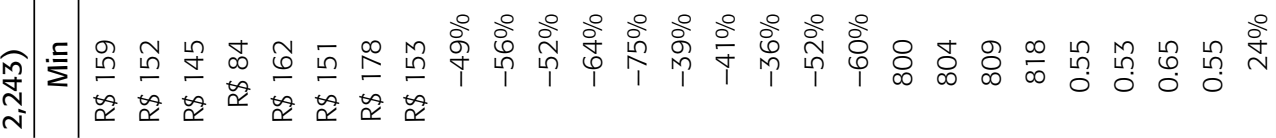

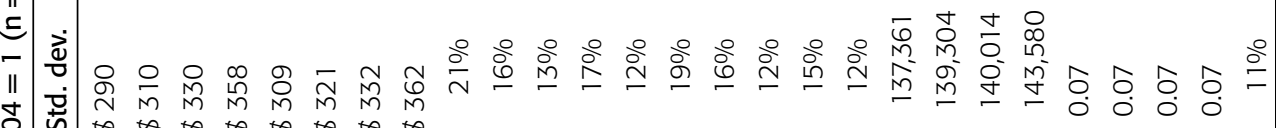

官

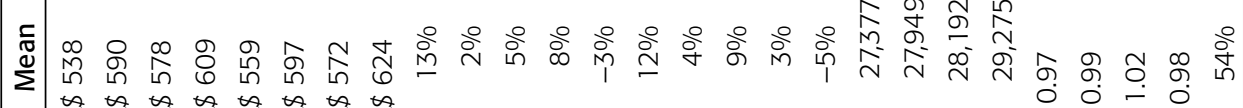

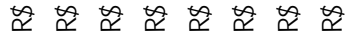

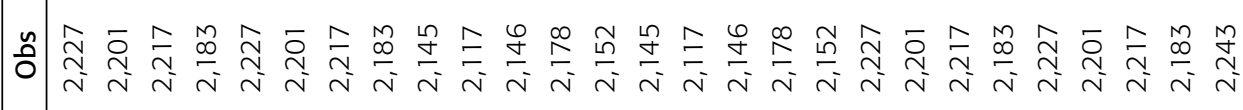

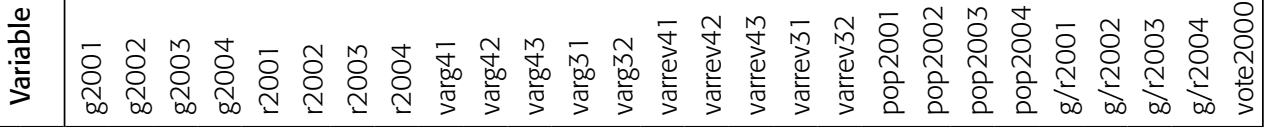


Tables 5 through 7 were developed to check whether the above figures are statistically significant, presenting the t-tests for the difference in means between the treatment and control groups. In general, most of the tests provide support for the preceding discussion. The tests suggest that besides and beyond the eligibility for reelection, it is the decision to run for reelection which constitutes the greater incentives for mayors to not only spend more, but also collect more during electoral years in order to increase their reelection chances without incurring in high deficits. This fact suggests that there are differences in the fiscal effort and capacity of reelectables and reelection runners as opposed to those of non-reelectables and non-runners.

Table 5

T-test of mean differences between groups

\begin{tabular}{|c|c|c|c|}
\hline \multirow{2}{*}{ Variable } & \multicolumn{3}{|c|}{ Reelectables vs. non-reelectables (REEL) } \\
\hline & Ho:reel $(1)-\operatorname{reel}(0)=0$ & Ha:reel $(1)-\operatorname{reel}(0)>0$ & Ha:reel $(1)-\operatorname{reel}(0)<0$ \\
\hline g2001 & & & ** \\
\hline g2002 & $* *$ & & \\
\hline g2003 & $* *$ & & \\
\hline g2004 & $* *$ & & \\
\hline r2001 & & & $* *$ \\
\hline r2002 & $* *$ & & \\
\hline r2003 & ** & & \\
\hline r2004 & $* *$ & & \\
\hline $\operatorname{varg} 41$ & & ** & \\
\hline $\operatorname{varg} 42$ & $* *$ & & \\
\hline varg43 & & & $* *$ \\
\hline varg31 & & $* *$ & \\
\hline varg32 & & $* *$ & \\
\hline varrev41 & & $* *$ & \\
\hline varrev42 & & $* *$ & \\
\hline varrev43 & $* *$ & & \\
\hline varrev31 & & $* *$ & \\
\hline
\end{tabular}




\begin{tabular}{|lccc|}
\hline \multirow{2}{*}{ Variable } & \multicolumn{3}{c|}{ Reelectables vs. non-reelectables (REEL) } \\
\cline { 2 - 4 } & Ho:reel $(1)-$ reel $(0)=0$ & Ha:reel $(1)-$ reel $(0)>0$ & Ha:reel $(1)-$ reel $(0)<0$ \\
\hline varrev32 & $* *$ & $* *$ & \\
pop2001 & $* *$ & & \\
pop2002 & $* *$ & & $* *$ \\
pop2003 & $* *$ & & \\
pop2004 & & & $*$ \\
$g /$ r2001 & & & $* *$ \\
$g /$ r2002 & & & $* *$ \\
$g /$ r2003 & & & $*$ \\
$g /$ r2004 & & & \\
vote2000 & & & \\
\hline
\end{tabular}

* $10 \%$ significance level.

** $5 \%$ significance level or lower.

Table 6

T-test of mean differences between groups

\begin{tabular}{|c|c|c|c|}
\hline \multirow{2}{*}{ Variable } & \multicolumn{3}{|c|}{ Reelection runners vs. non-reelectables (RUNO4 x REEL) } \\
\hline & Ho:run04(1) $-\operatorname{reel}(0)=0$ & Ha:run04(1) - reel $(0)>0$ & Ha:run04(1) $-\operatorname{reel}(0)<0$ \\
\hline g2001 & & & $* *$ \\
\hline g2002 & $* *$ & & \\
\hline g2003 & ** & & \\
\hline g2004 & ** & & \\
\hline r2001 & & & * \\
\hline r2002 & $* *$ & & \\
\hline r2003 & $* *$ & & \\
\hline r2004 & $* *$ & & \\
\hline varg41 & & $* *$ & \\
\hline $\operatorname{varg} 42$ & $* *$ & & \\
\hline
\end{tabular}




\begin{tabular}{|c|c|c|c|}
\hline \multirow{2}{*}{ Variable } & \multicolumn{3}{|c|}{ Reelection runners vs. non-reelectables (RUNO4 x REEL) } \\
\hline & Ho:run04(1) $-\operatorname{reel}(0)=0$ & Ha:run04(1) - reel(0)>0 & Ha:run04(1) $-\operatorname{reel}(0)<0$ \\
\hline varg43 & & & $* *$ \\
\hline varg31 & & $* *$ & \\
\hline varg32 & & $* *$ & \\
\hline varrev41 & & ** & \\
\hline varrev42 & & ** & \\
\hline varrev43 & $* *$ & & \\
\hline varrev31 & & $* *$ & \\
\hline varrev32 & & $* *$ & \\
\hline pop2001 & & & * \\
\hline pop2002 & & & * \\
\hline pop2003 & & & * \\
\hline pop2004 & & & $*$ \\
\hline g/r2001 & & & ** \\
\hline g/r2002 & $* *$ & & \\
\hline g/r2003 & ** & & \\
\hline g/r2004 & & & $* *$ \\
\hline vote 2000 & & & ** \\
\hline
\end{tabular}

* 10\% significance level.

** 5\% significance level or lower.

Table 7

T-test of mean differences between groups

\begin{tabular}{|cc|}
\hline \multirow{2}{*}{ Variable } & Reelection runners vs. non-runners (RUN04) \\
\cline { 2 - 3 } & Ho:run04(1) - run04(0) $=0$ Ha:run04(1) $-\operatorname{run04}(0)>0$ Ha:run04 $(1)-\operatorname{run04}(0)<0$ \\
\hline g2001 & $* *$ \\
g2002 & $*$ \\
g2003 & $* *$ \\
\hline
\end{tabular}




\begin{tabular}{|c|c|c|c|}
\hline \multirow{2}{*}{ Variable } & \multicolumn{3}{|c|}{ Reelection runners vs. non-runners (RUN04) } \\
\hline & Ho:run04(1) $-\operatorname{run04}(0)=0$ & Ha:run04(1) $-\operatorname{run04}(0)>0$ & Ha:run04 $(1)-\operatorname{run04}(0)<0$ \\
\hline g2004 & & ** & \\
\hline r2001 & ** & & \\
\hline r2002 & & $*$ & \\
\hline r2003 & & ** & \\
\hline r2004 & & $* *$ & \\
\hline varg41 & & ** & \\
\hline $\operatorname{varg} 42$ & & $*$ & \\
\hline $\operatorname{varg} 43$ & ** & & \\
\hline varg31 & & $* *$ & \\
\hline varg32 & $* *$ & & \\
\hline varrev41 & & $* *$ & \\
\hline varrev42 & $* *$ & & \\
\hline varrev43 & $* *$ & & \\
\hline varrev31 & & $* *$ & \\
\hline varrev32 & $* *$ & & \\
\hline pop2001 & $* *$ & & \\
\hline pop2002 & $* *$ & & \\
\hline pop2003 & $* *$ & & \\
\hline pop2004 & $* *$ & & \\
\hline g/r2001 & & & $* *$ \\
\hline g/r2002 & ** & & \\
\hline$g / r 2003$ & $* *$ & & \\
\hline $\mathrm{g} / \mathrm{r} 2004$ & & $* *$ & \\
\hline vote2000 & ** & & \\
\hline
\end{tabular}

* 10\% significance level.

** 5\% significance level or lower. 


\section{Econometric results}

Results for testing equation 4 using the difference-in-differences (DD) econometric method are reported in tables 8 through 19 . There are three groups of tables, corresponding to the three different classifications for the treatment and control groups: (i) reelectables vs. non-reelectables (tables 8 through 11); (ii) reelection runners vs. non-reelectables (tables 12 through 15); and (iii) reelection runners vs. non-runners (tables 16 through 19). For each of the three pairs, there are four tables, each corresponding to a chosen period of two years representing the electoral and non-electoral years (2004 vs. 2001,2004 vs. 2002, 2003 vs. 2001, and 2003 vs. 2002). On each table, two alternative measures for the dependent variable are used: a) the natural log of the real government spending per capita (ln$\left.g_{i t}\right)$, and b) the deficit ratio $\left(g_{i t} / r_{i t}\right)$. The main variables of interest are the third ones (t04_reel, t03_reel, t04_run04 and t03_run04), which capture the DD (treatment) effect of the average difference in spending between the treatment and control groups. All tables include five columns, where columns 1 reflect the unconditional specification of equation 4 (no control variables included), while columns 5 reflect the complete specification as suggested in (4), where the treatment is interacted with all the covariates. Before proceeding to a more detailed analysis of each case, note that in all tables the complete specification (columns 5) significantly alters the results. In almost every case, the inclusion of the interaction terms (specially the interaction with the log of population) resulted in a large change in the treatment effect coefficient. The low statistical significance of the interaction terms indicates that the treatment effect does not respond to these controls whenever it is conditioned to them. Moreover, the inclusion of the interacted terms did not improve the R-squared, which leaves open the question as to whether the interactions are relevant, since they do not add any explanatory power to the model. Therefore, the following discussion is only based on the results of columns 1 through 4 .

Looking at the reelectables vs. non-reelectables group (tables 8-11), it can be seen that reelectables have a variation in government spending that ranges from zero (no statistical difference) to $3.6 \%$ higher than that of nonreelectables, depending on the years used as electoral and non-electoral years. As for their deficit ratios, they range from $1.3 \%$ lower to $0.68 \%$ higher than those of non-reelectables. 


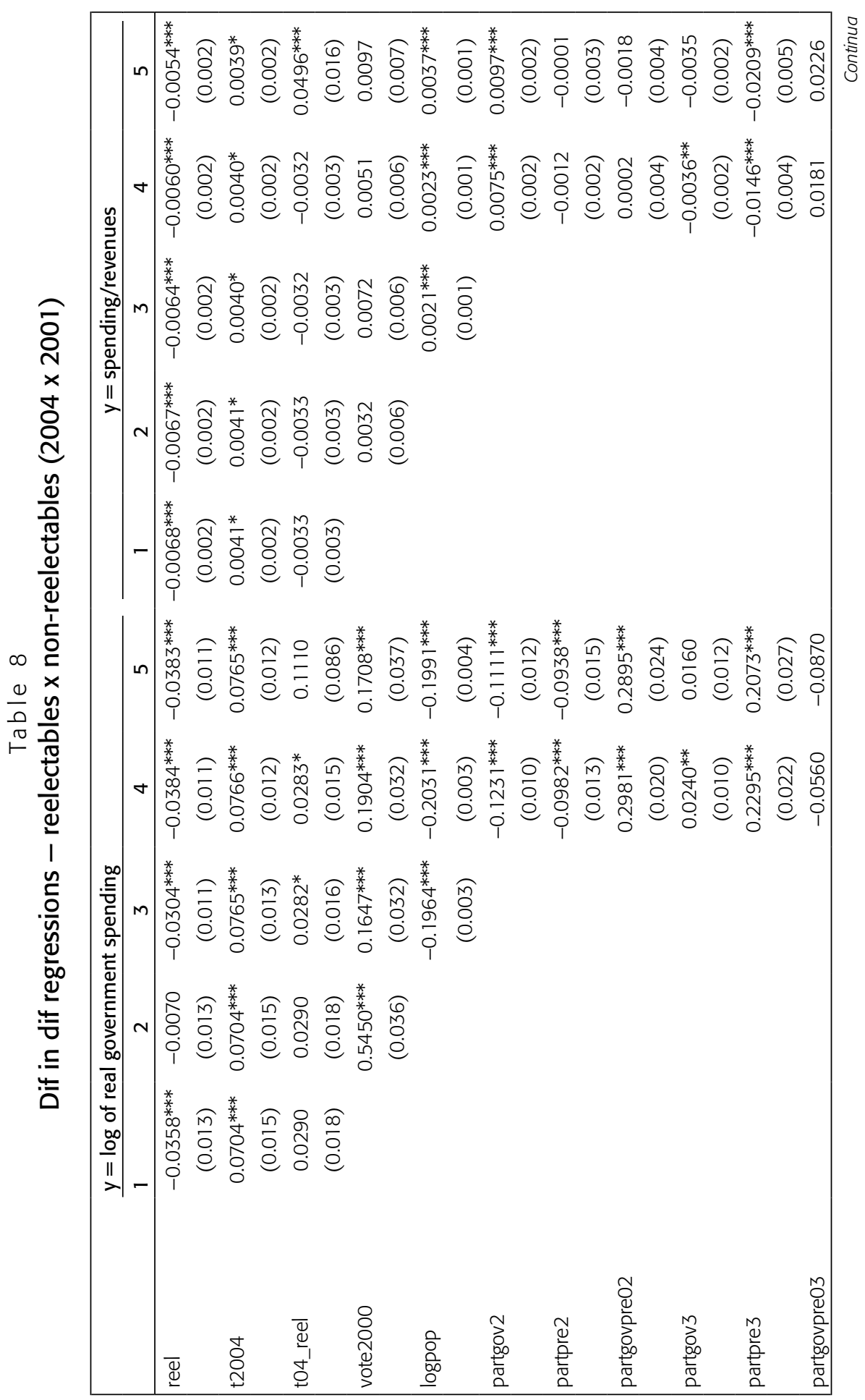

RAP - RIO DE JANEIRO 44(2):283-337, MAR./ABR. 2010 


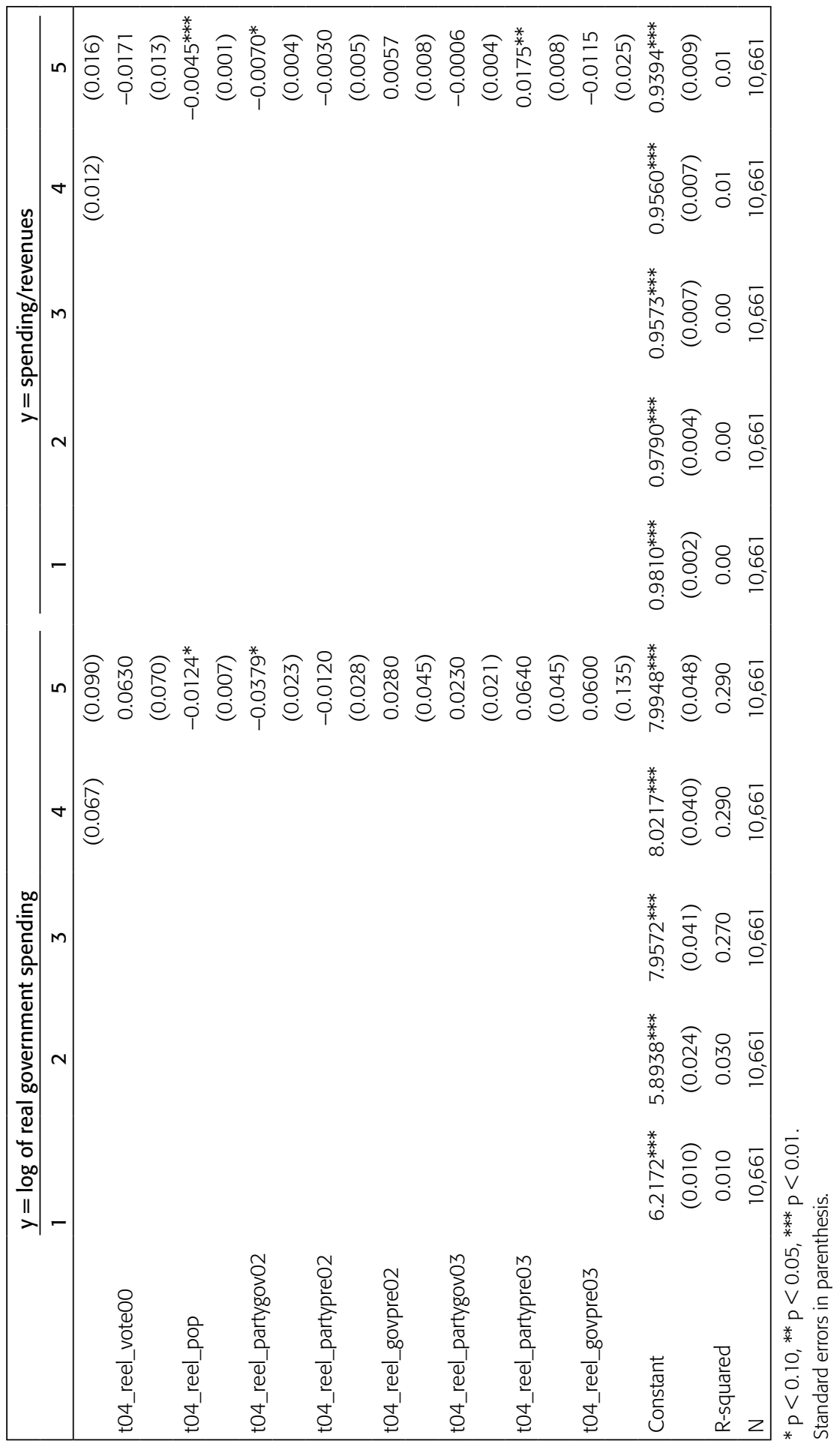

RAP - RIO DE JANEIRO 44(2):283-337, MAR./ABR. 2010 


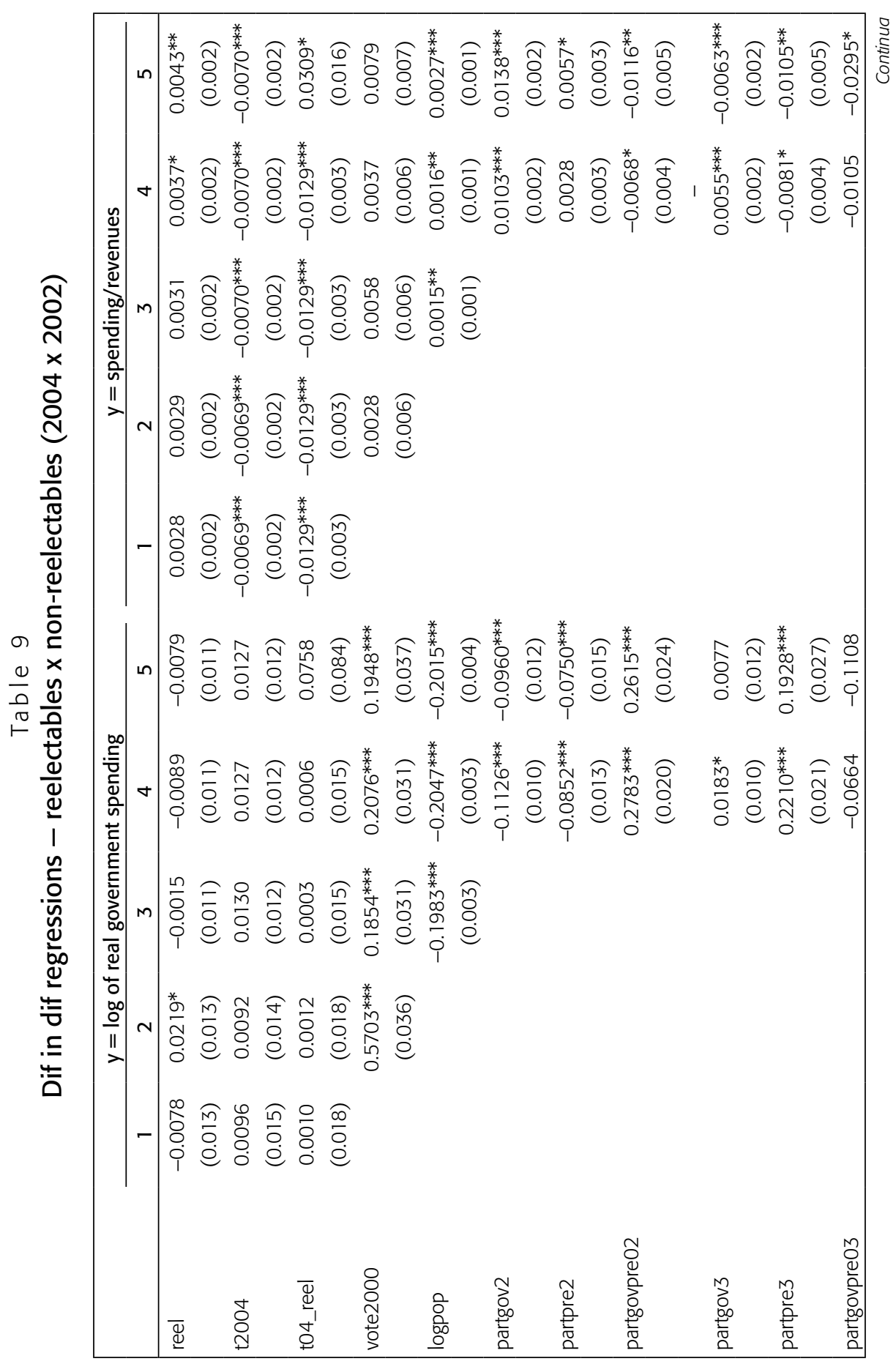




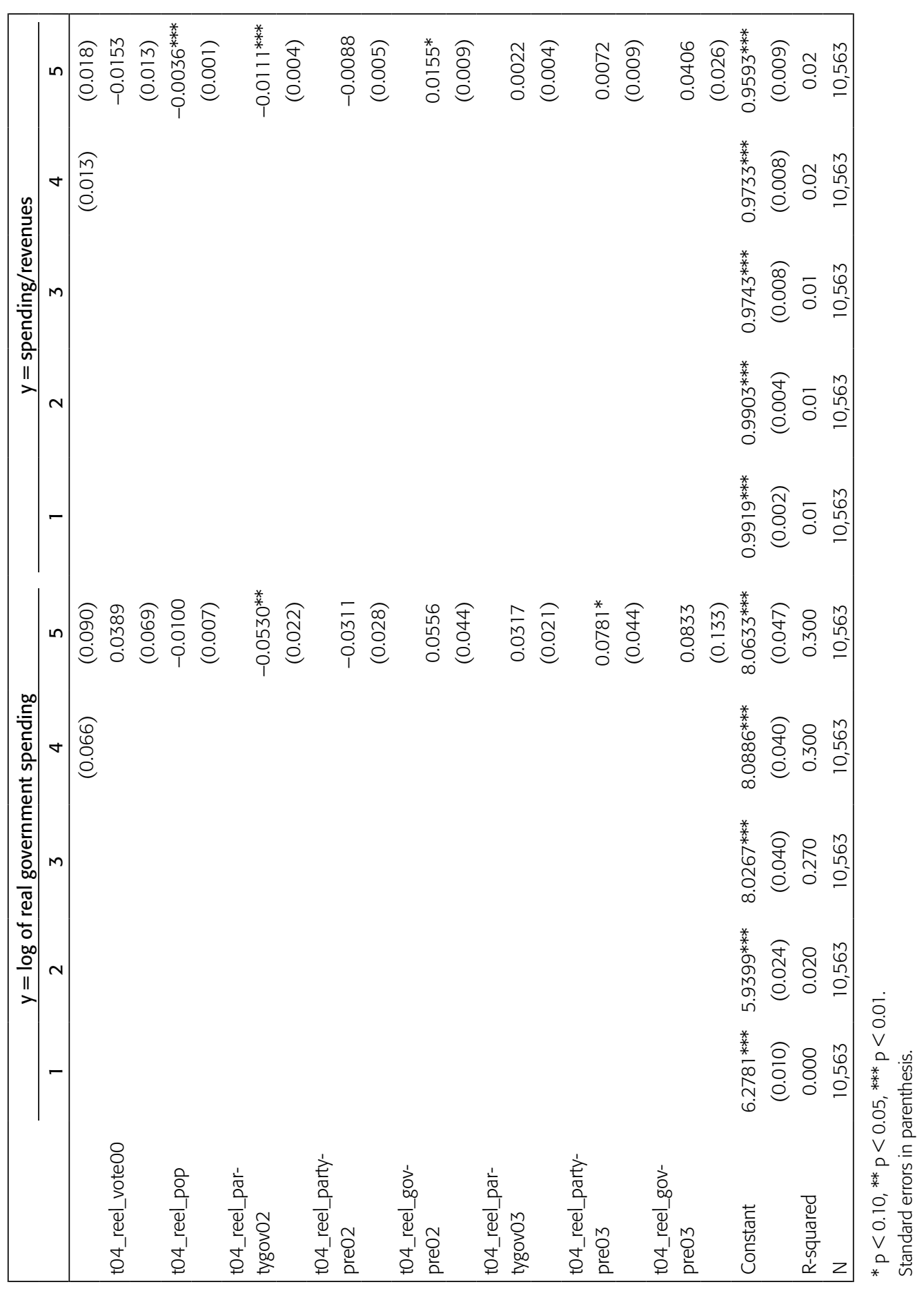

RAP - RIO DE JANEIRO 44(2):283-337, MAR./ABR. 2010 


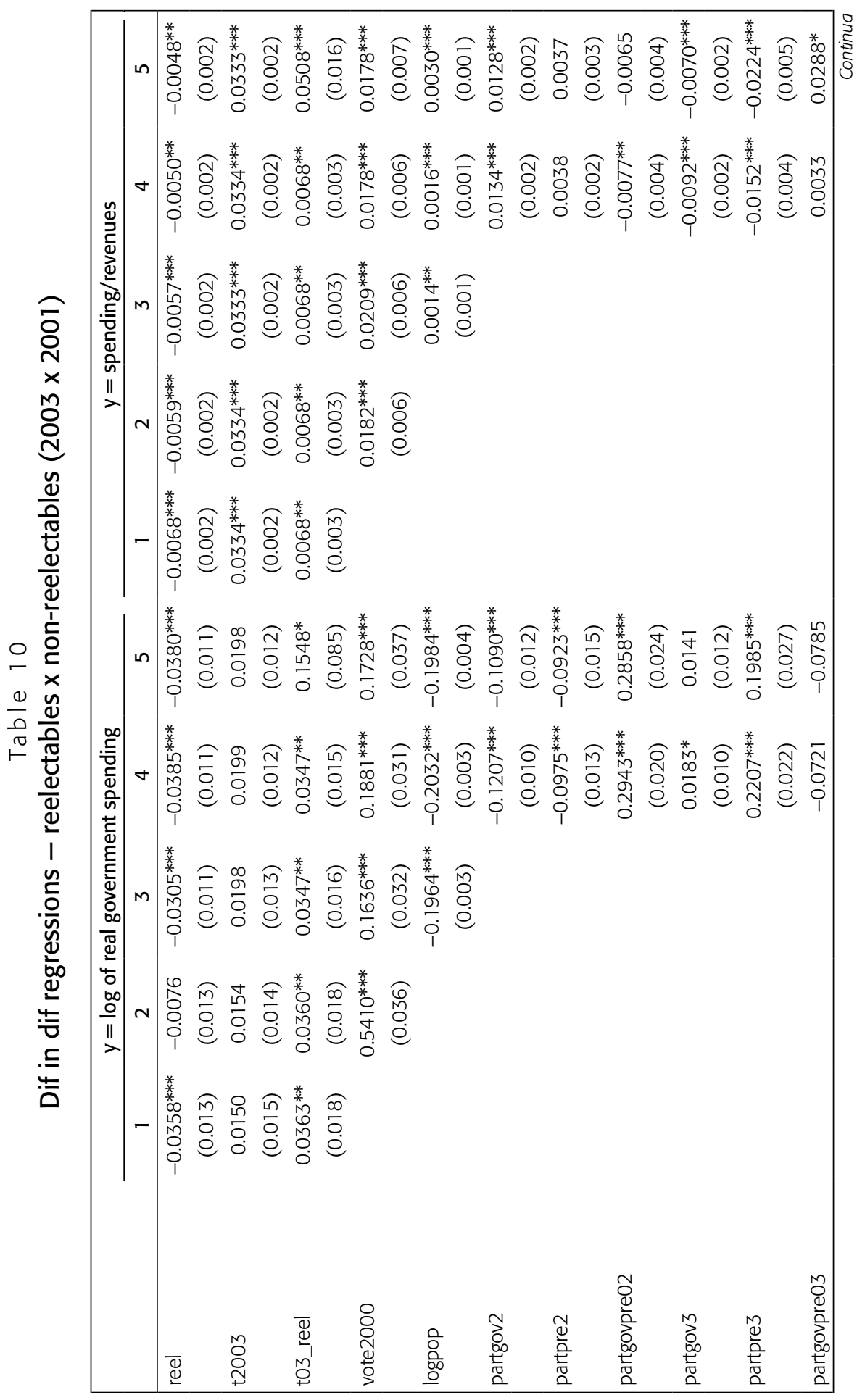

RAP - RIO DE JANEIRO 44(2):283-337, MAR./ABR. 2010 


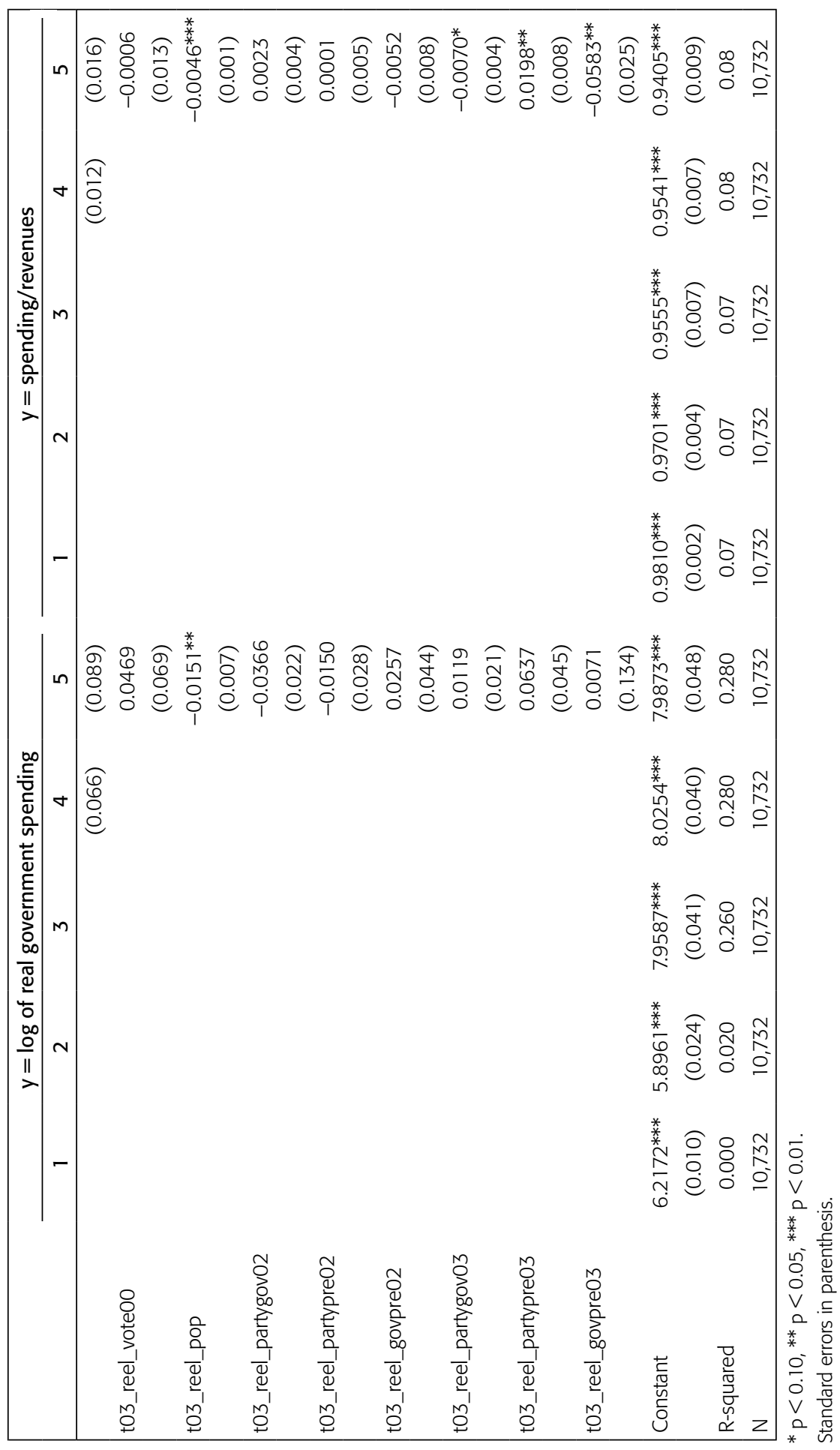

RAP - RIO DE JANEIRO 44(2):283-337, MAR./ABR. 2010 


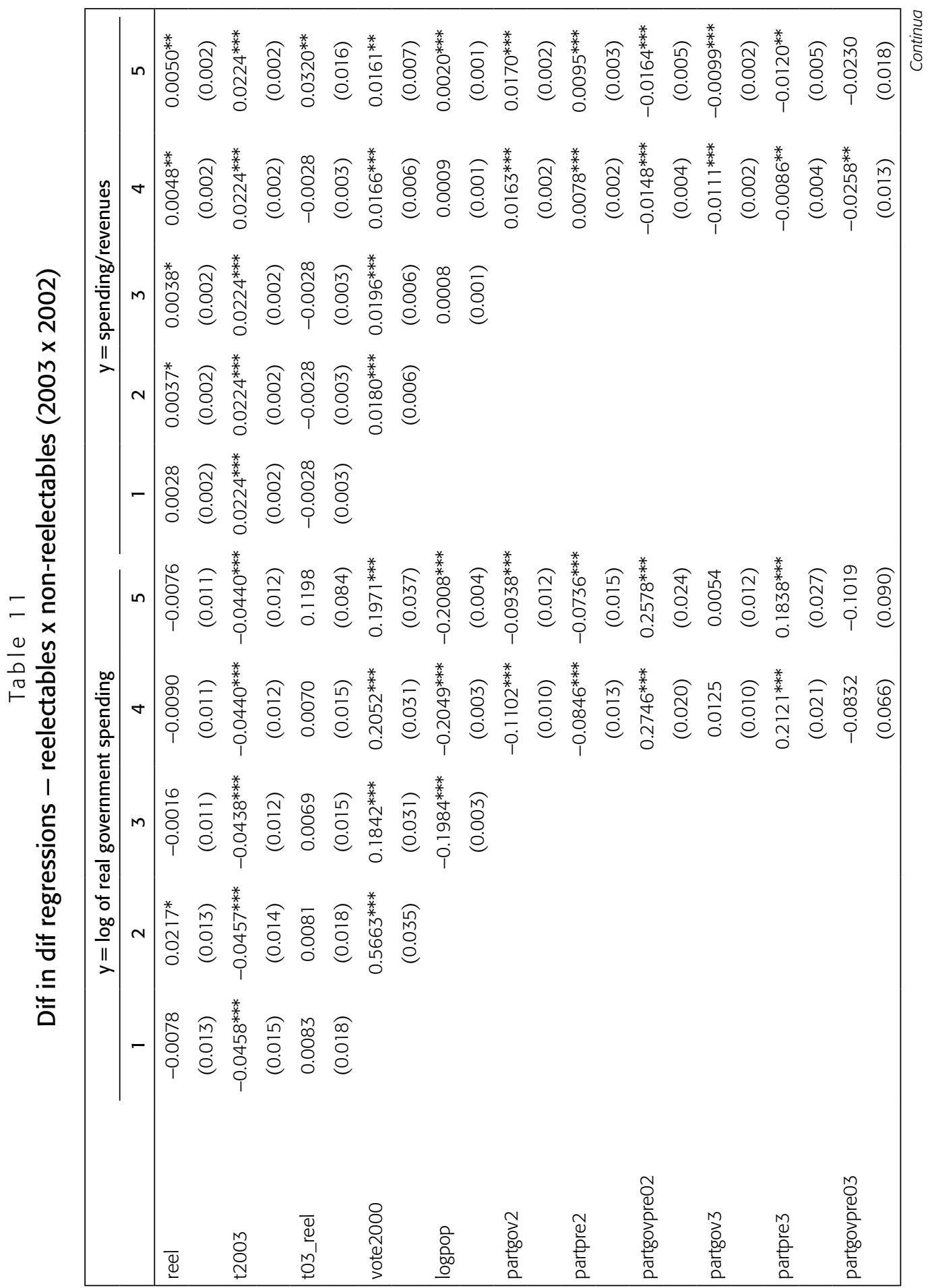




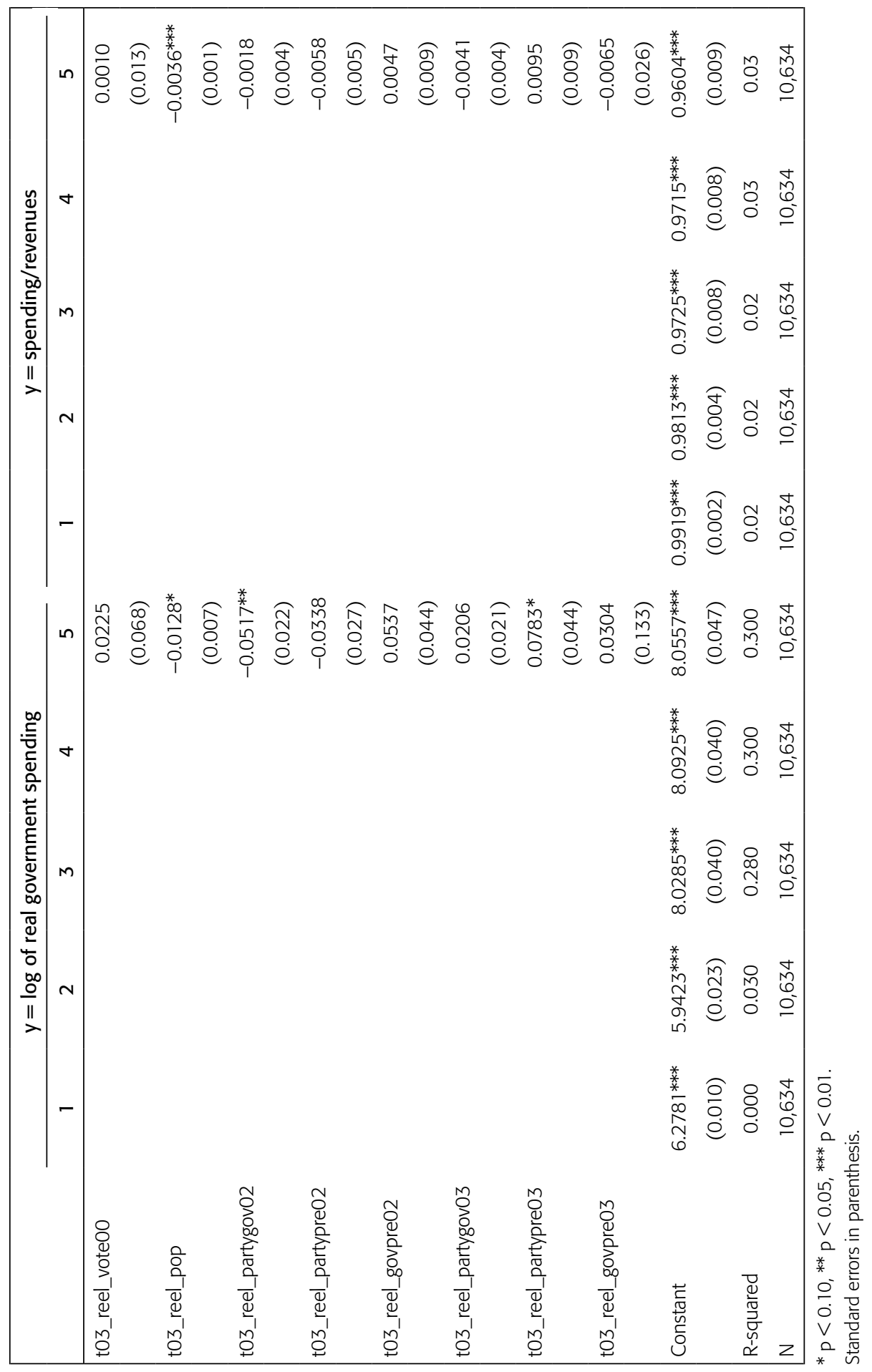

RAP - RIO DE JANEIRO 44(2):283-337, MAR./ABR. 2010 


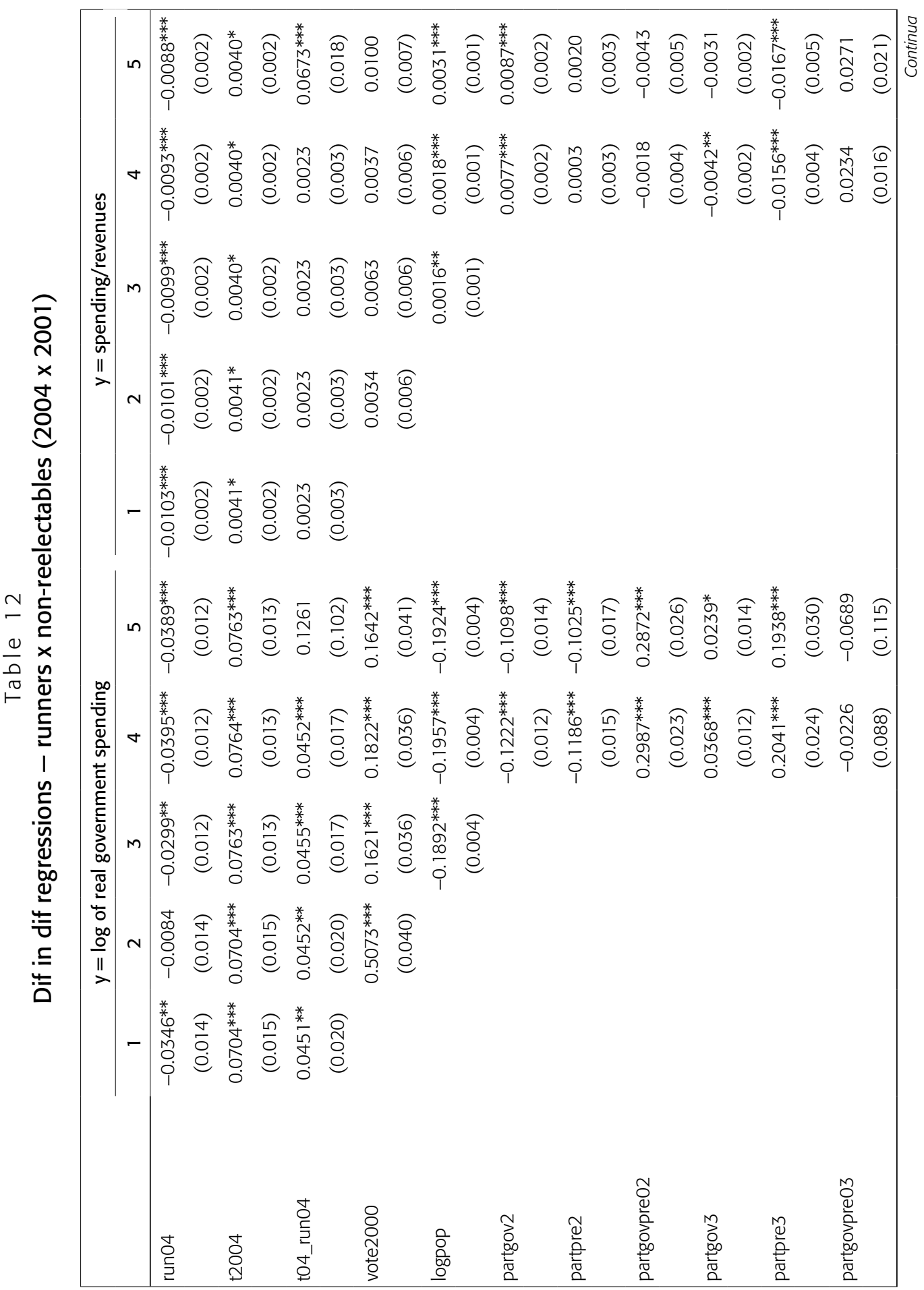




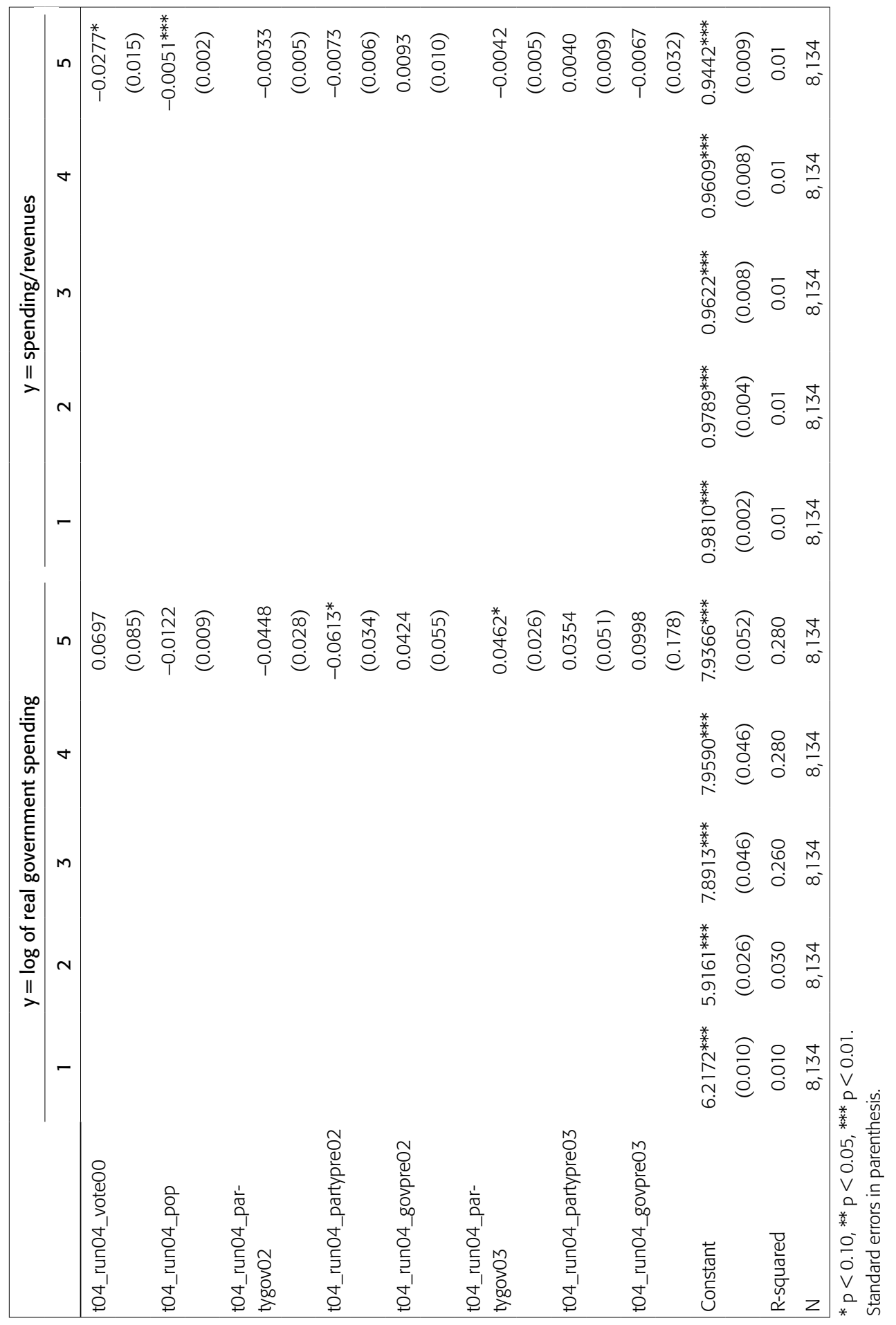

RAP - RIO DE JANEIRO 44(2):283-337, MAR./ABR. 2010 


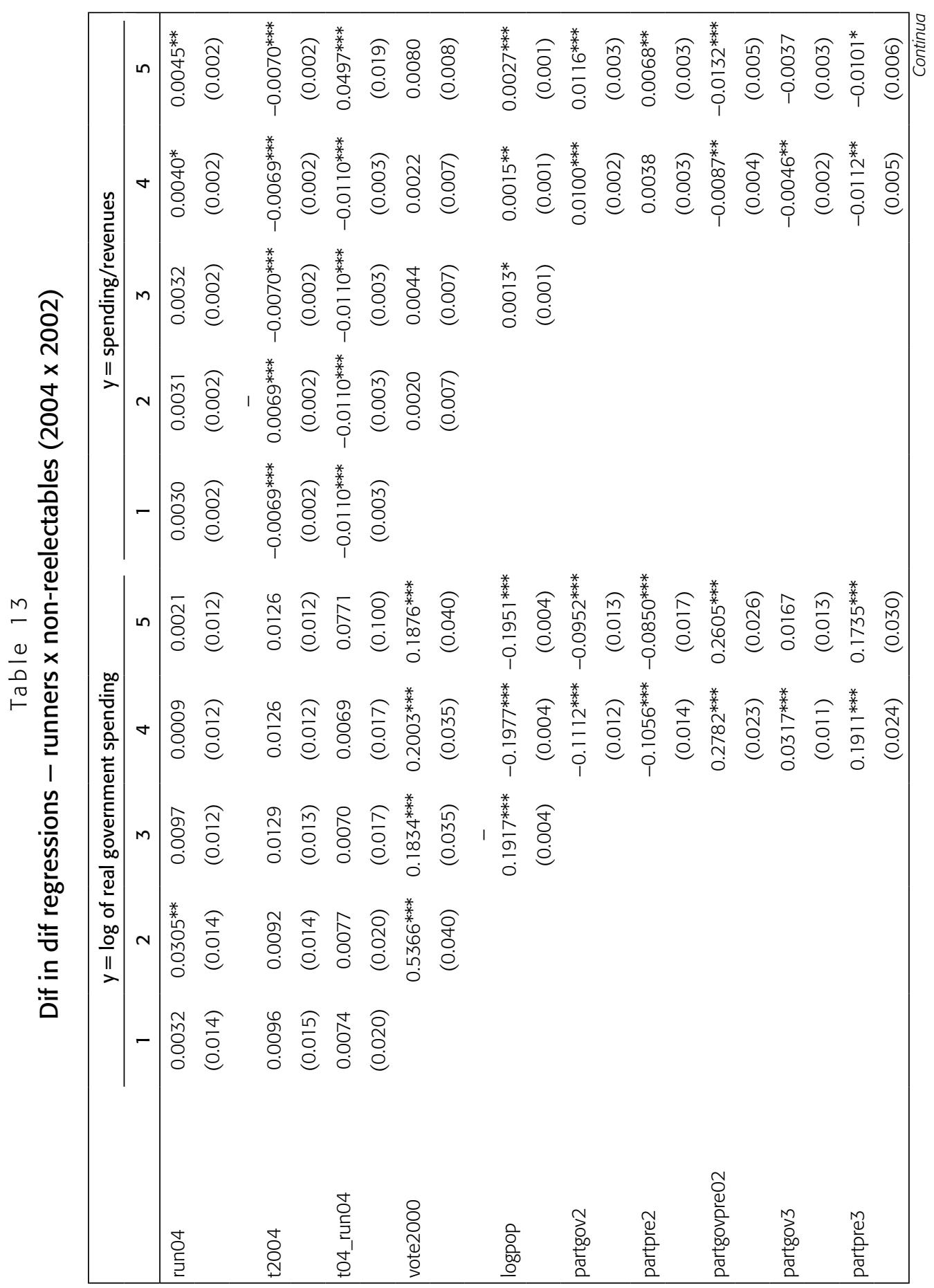




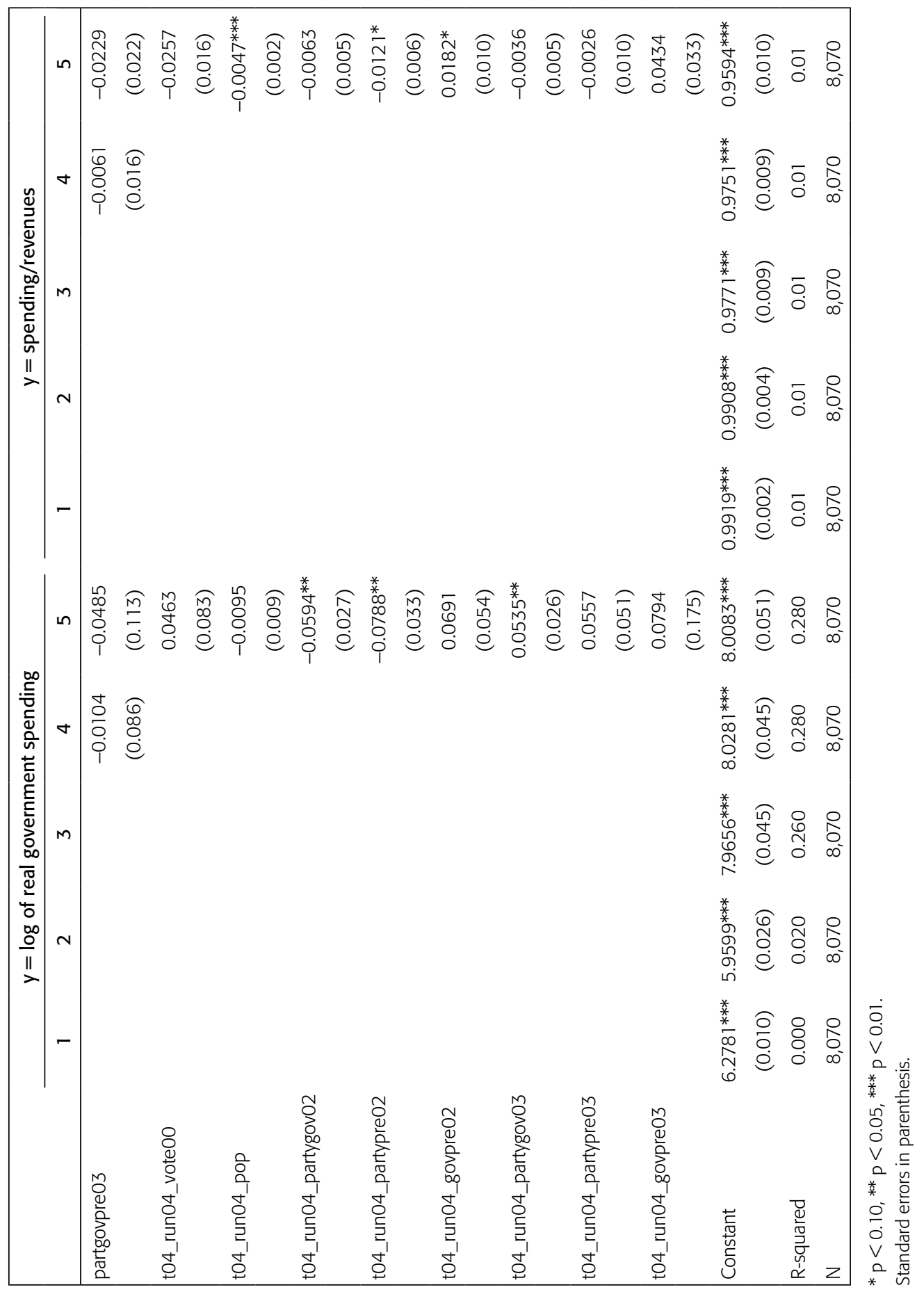




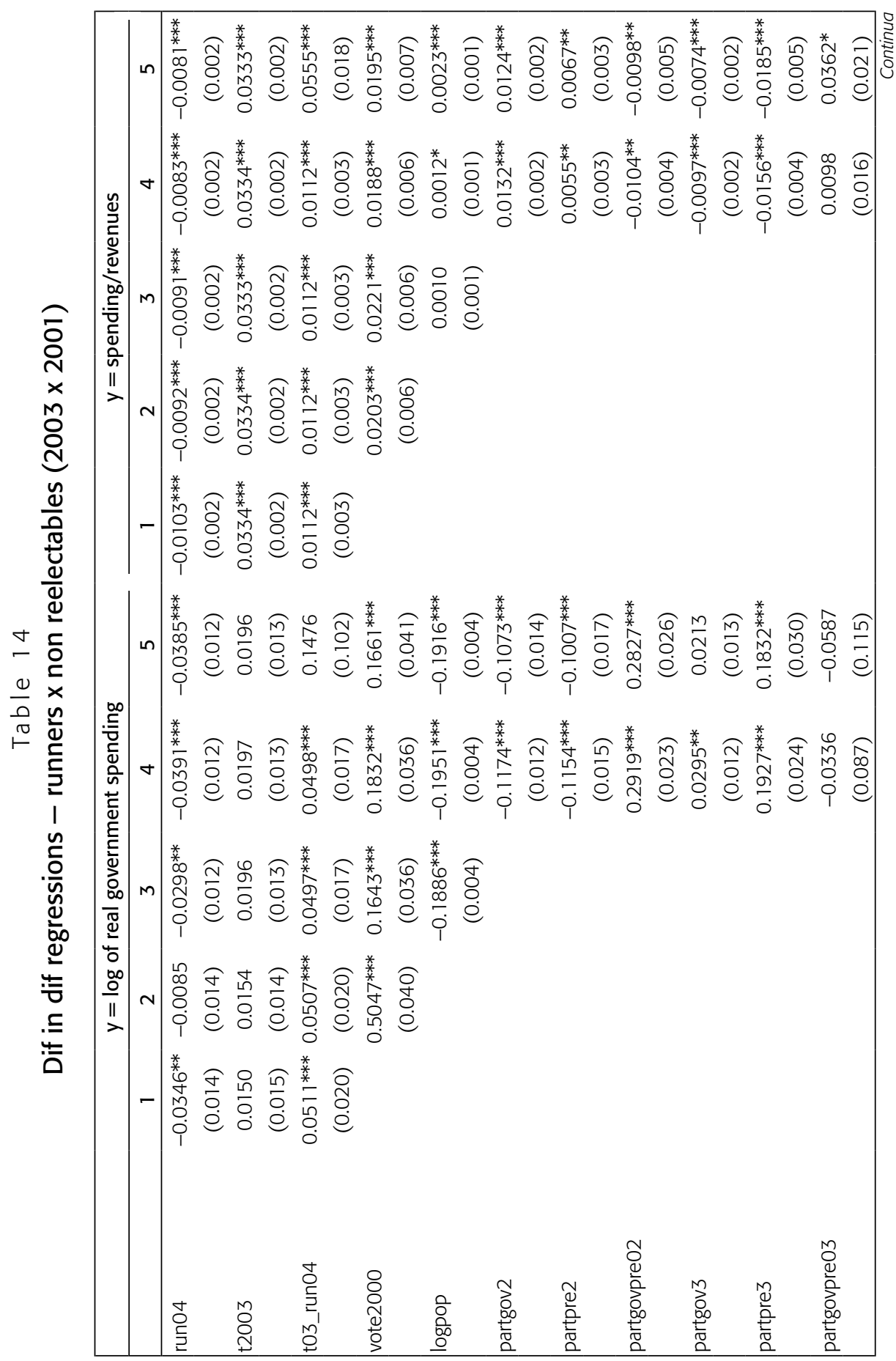




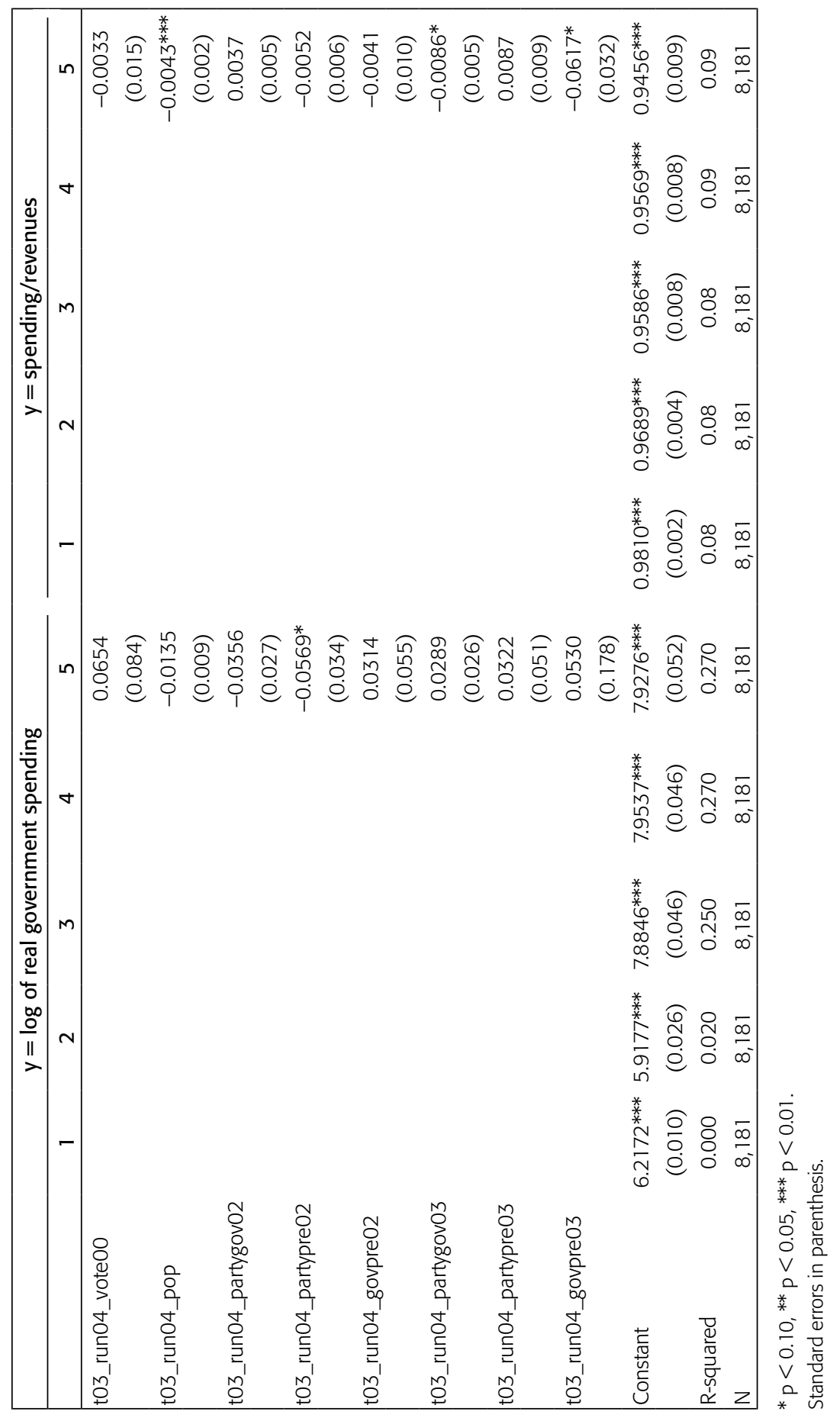




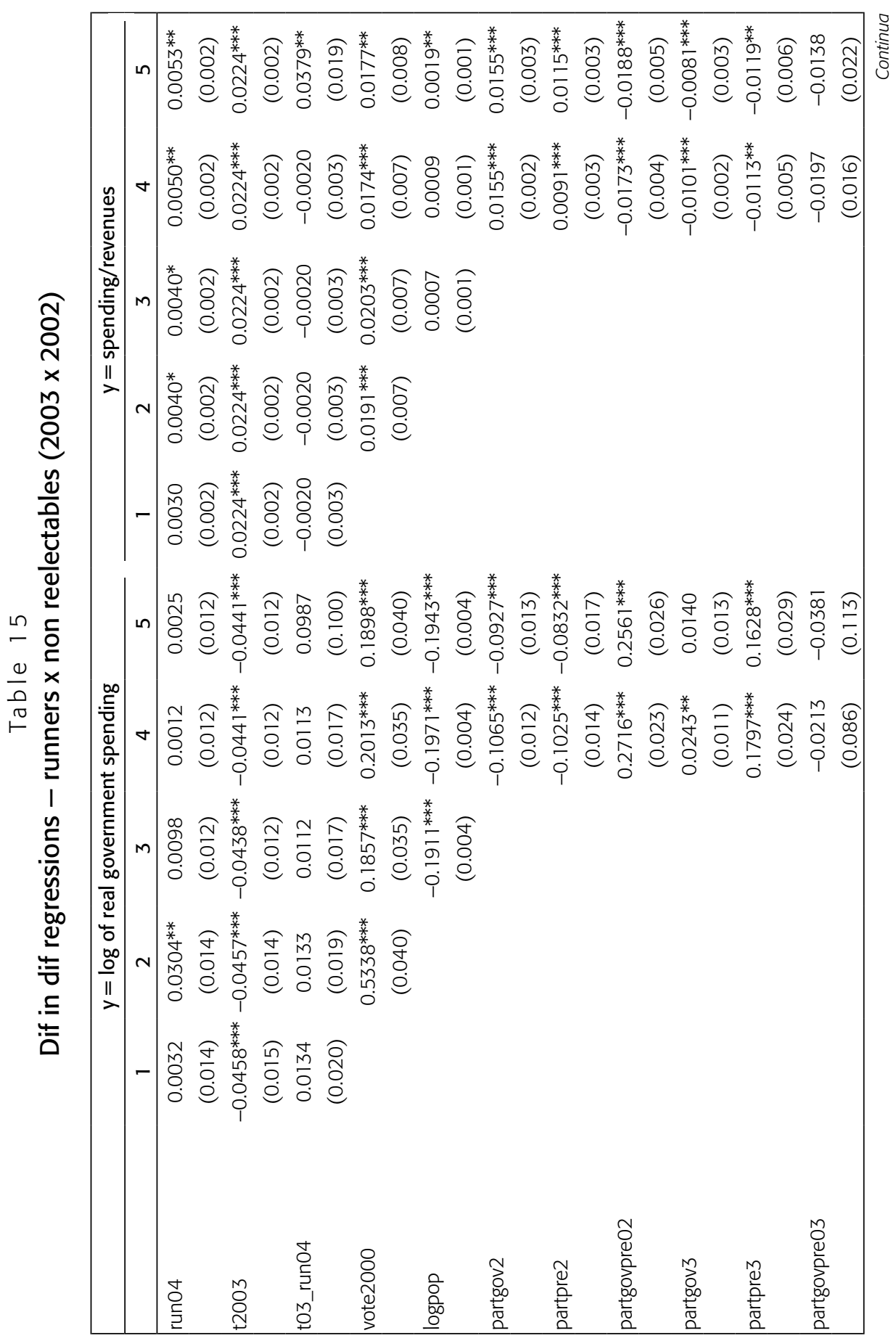




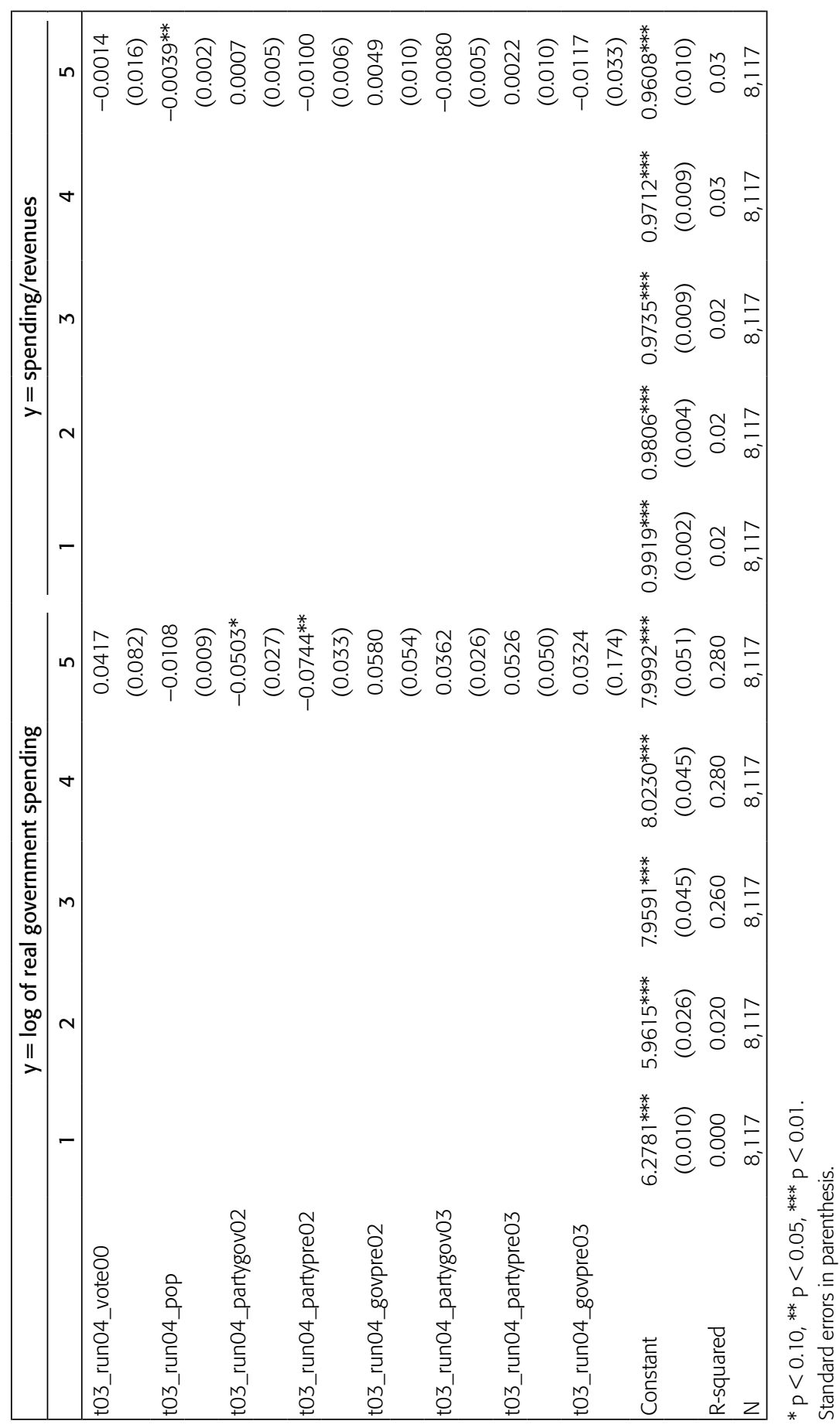




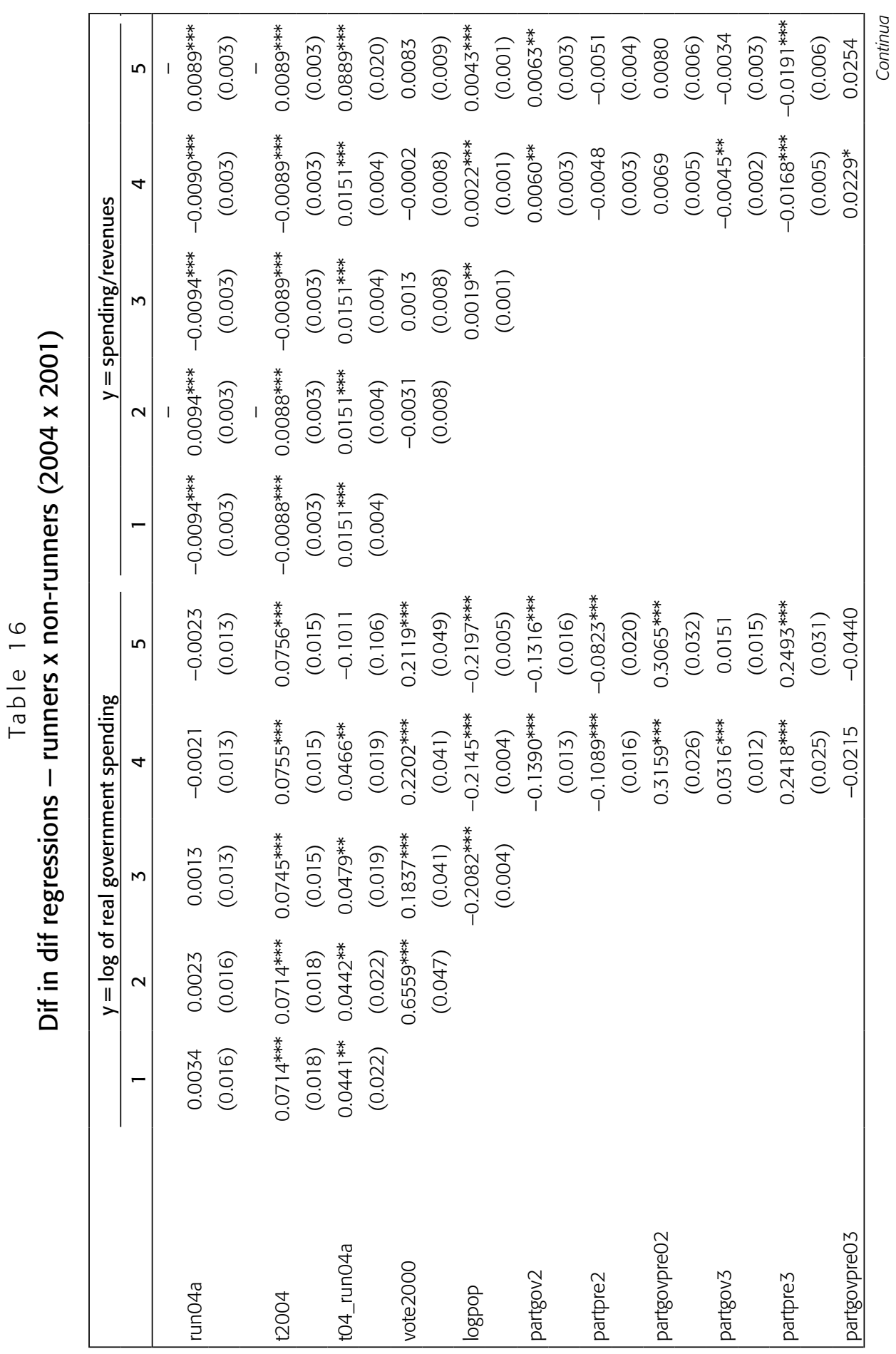




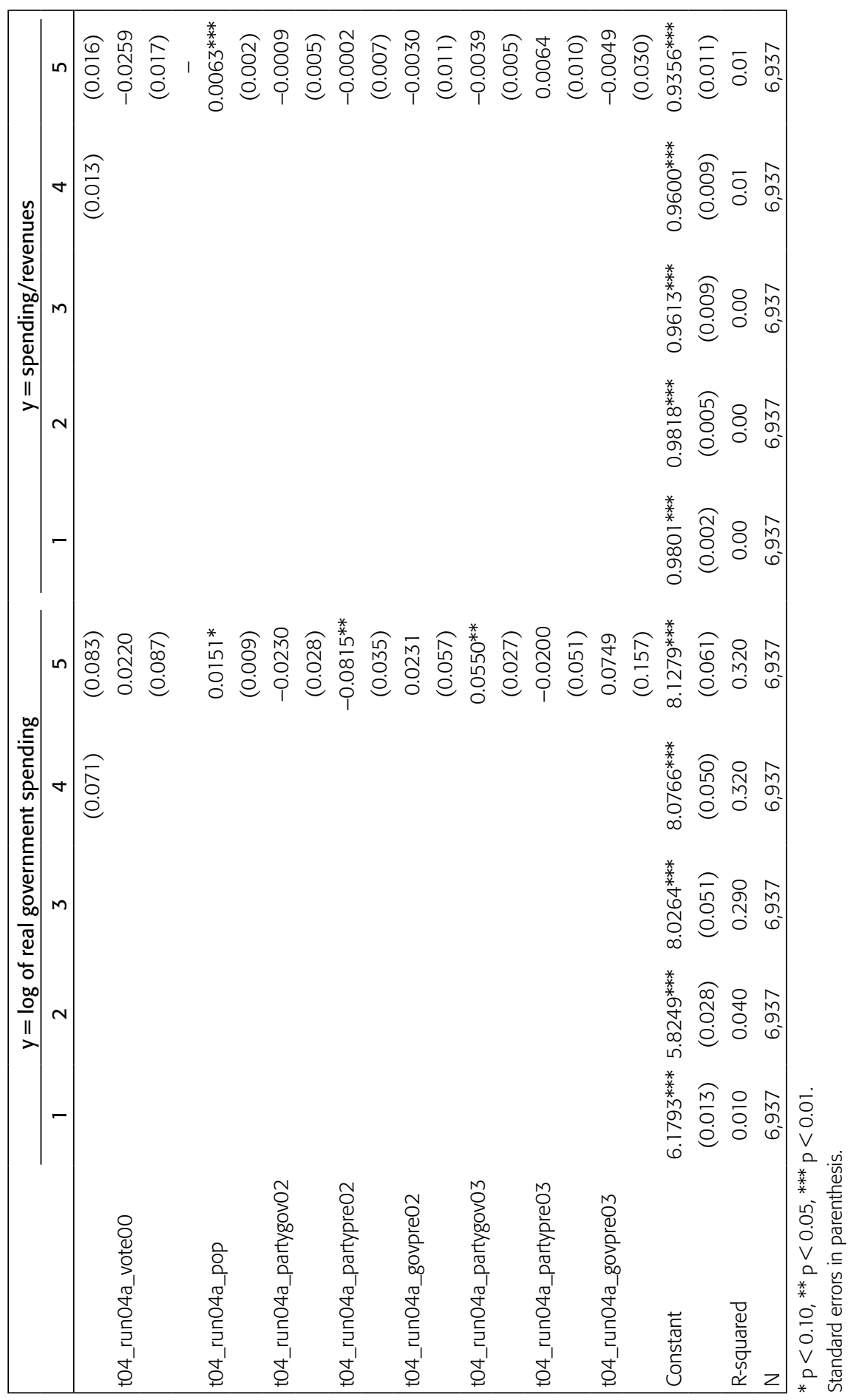

RAP - RIO DE JANEIRO 44(2):283-337, MAR./ABR. 2010 


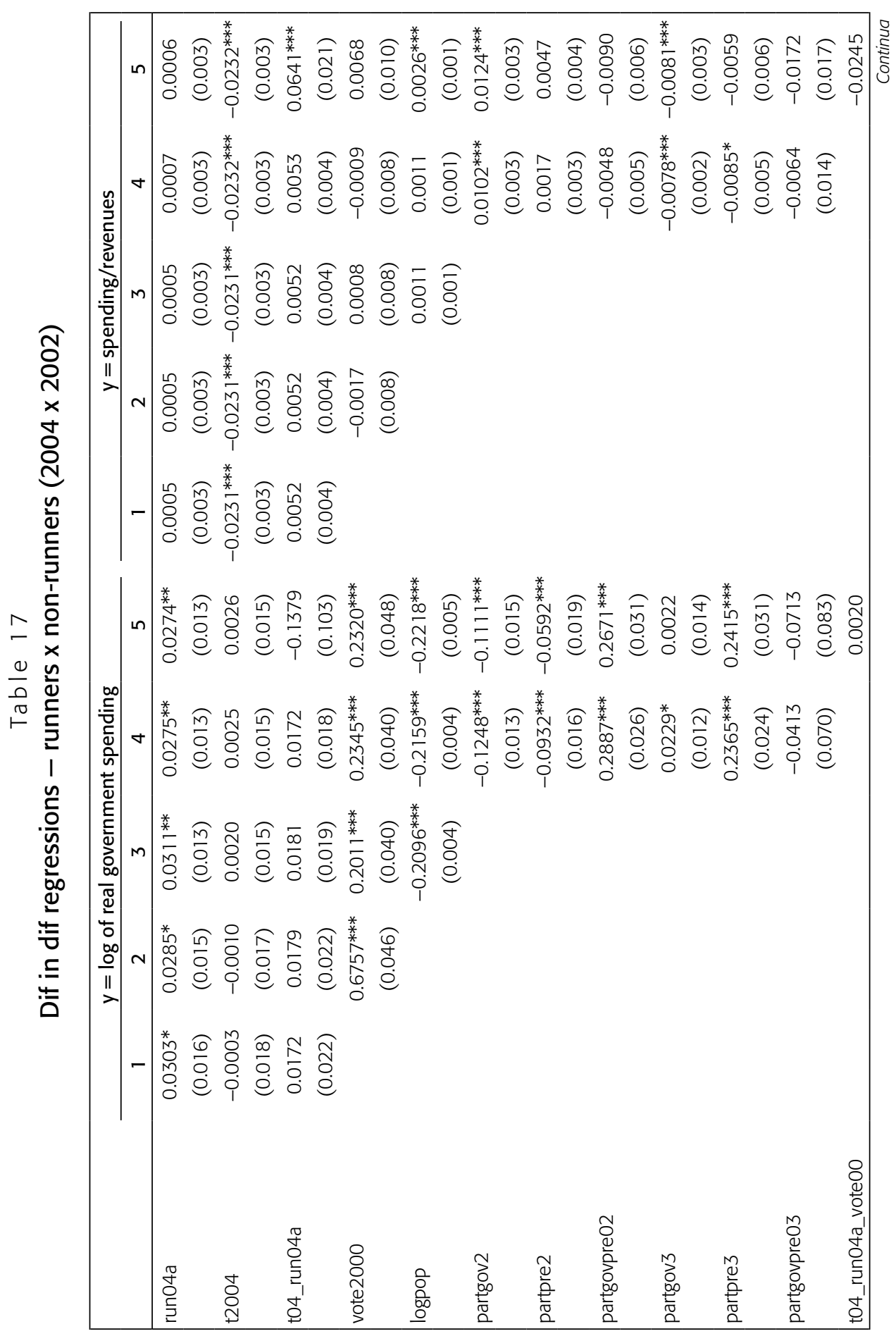




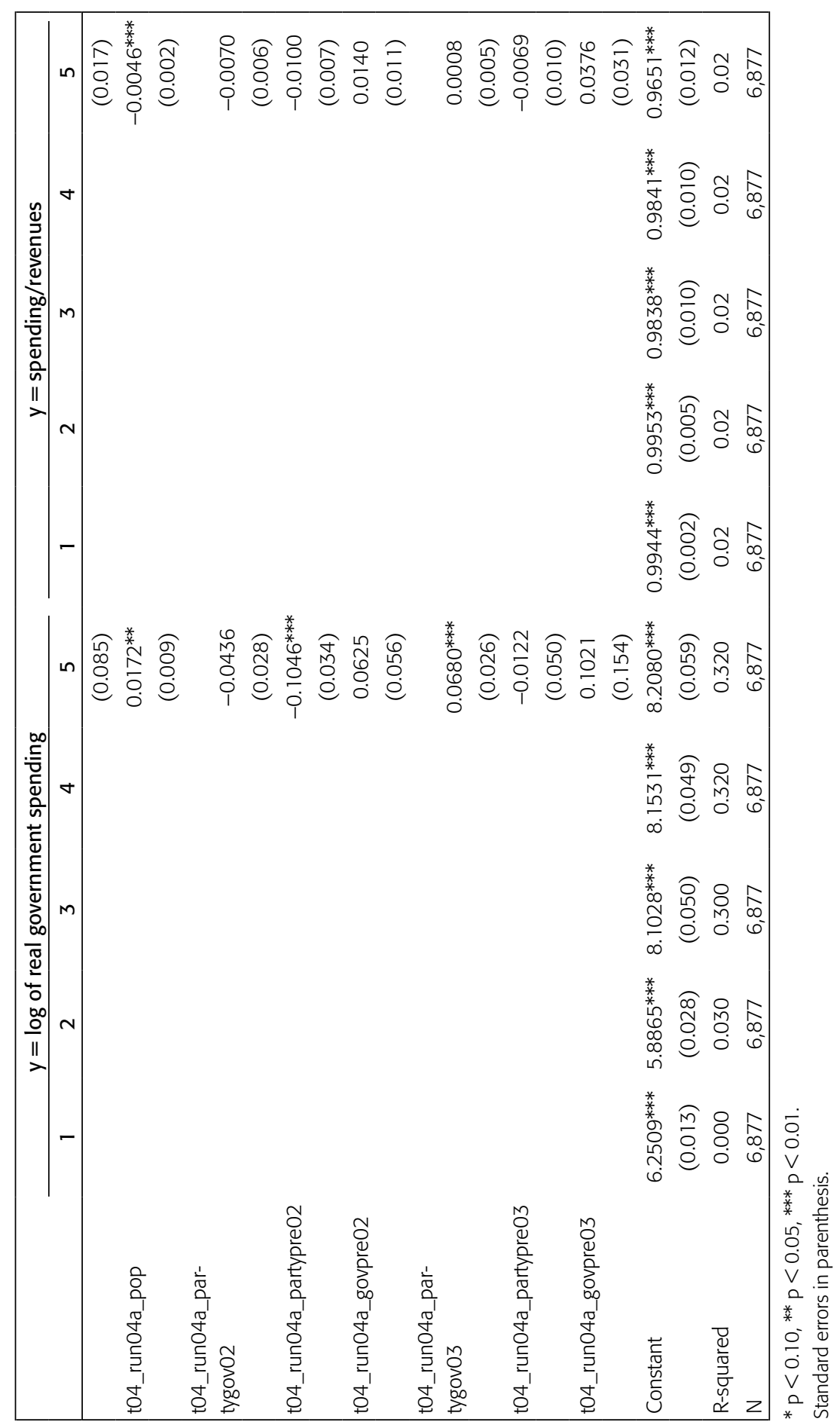

RAP - RIO DE JANEIRO 44(2):283-337, MAR./ABR. 2010 


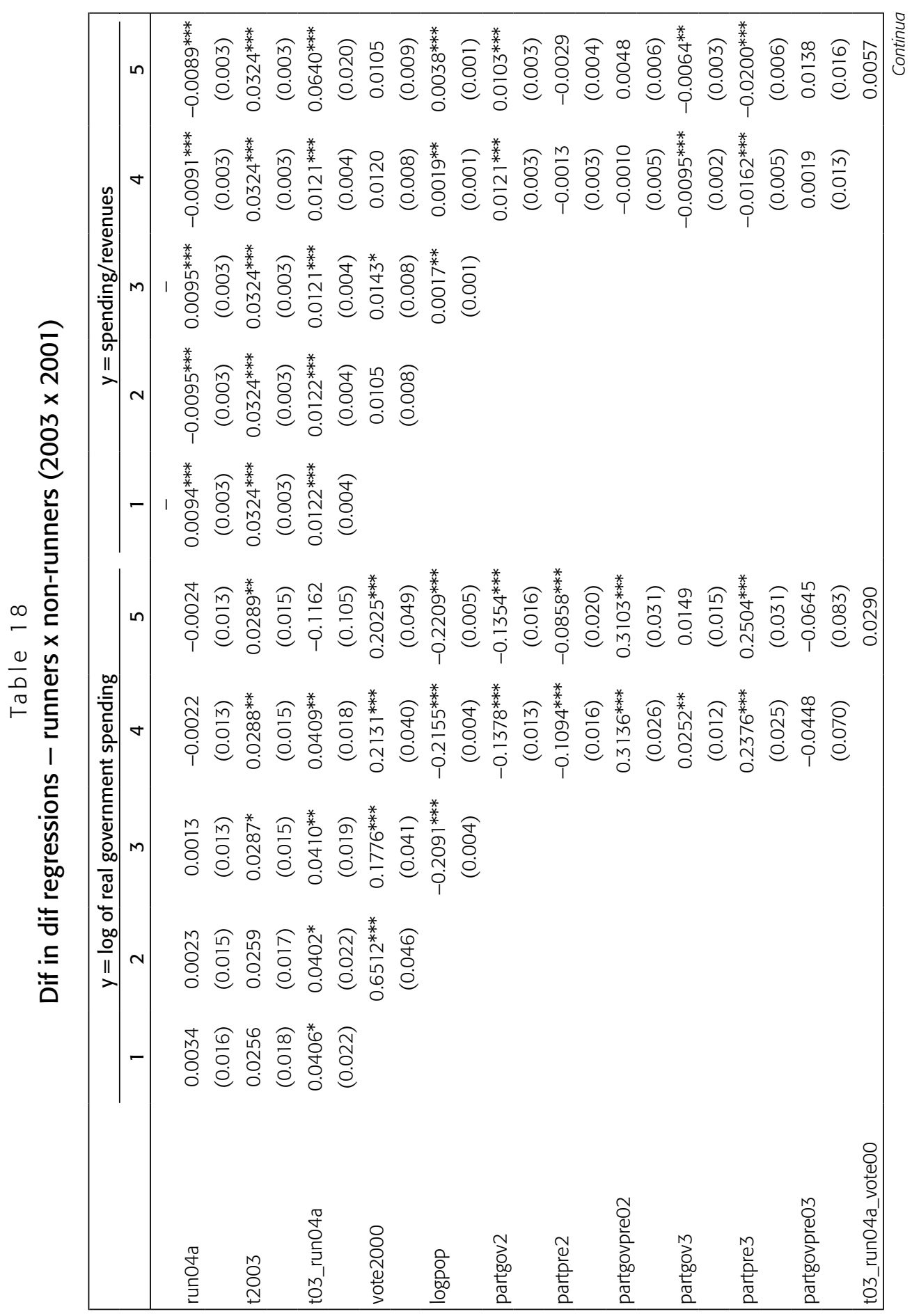




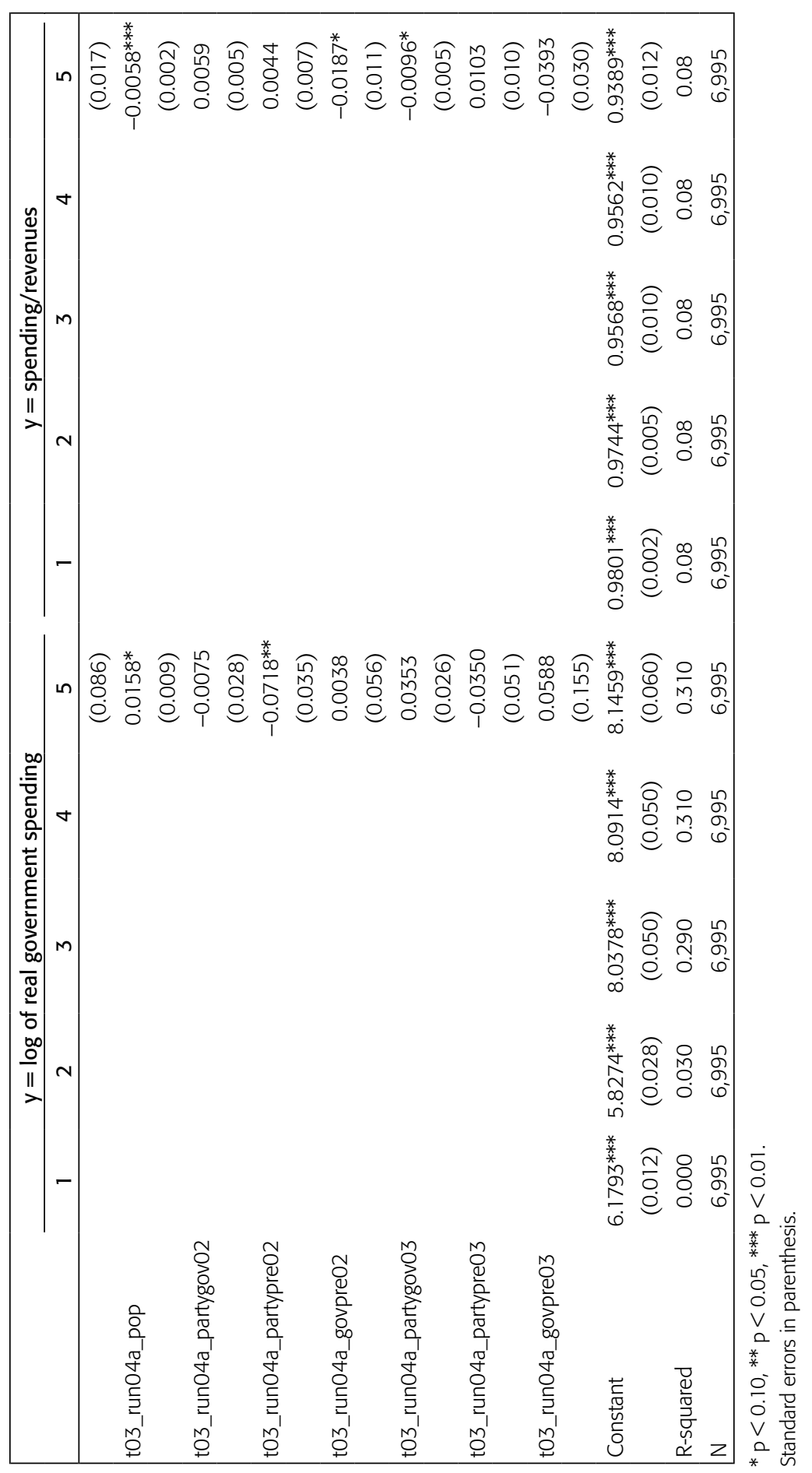

RAP - RIO DE JANEIRO 44(2):283-337, MAR./ABR. 2010 


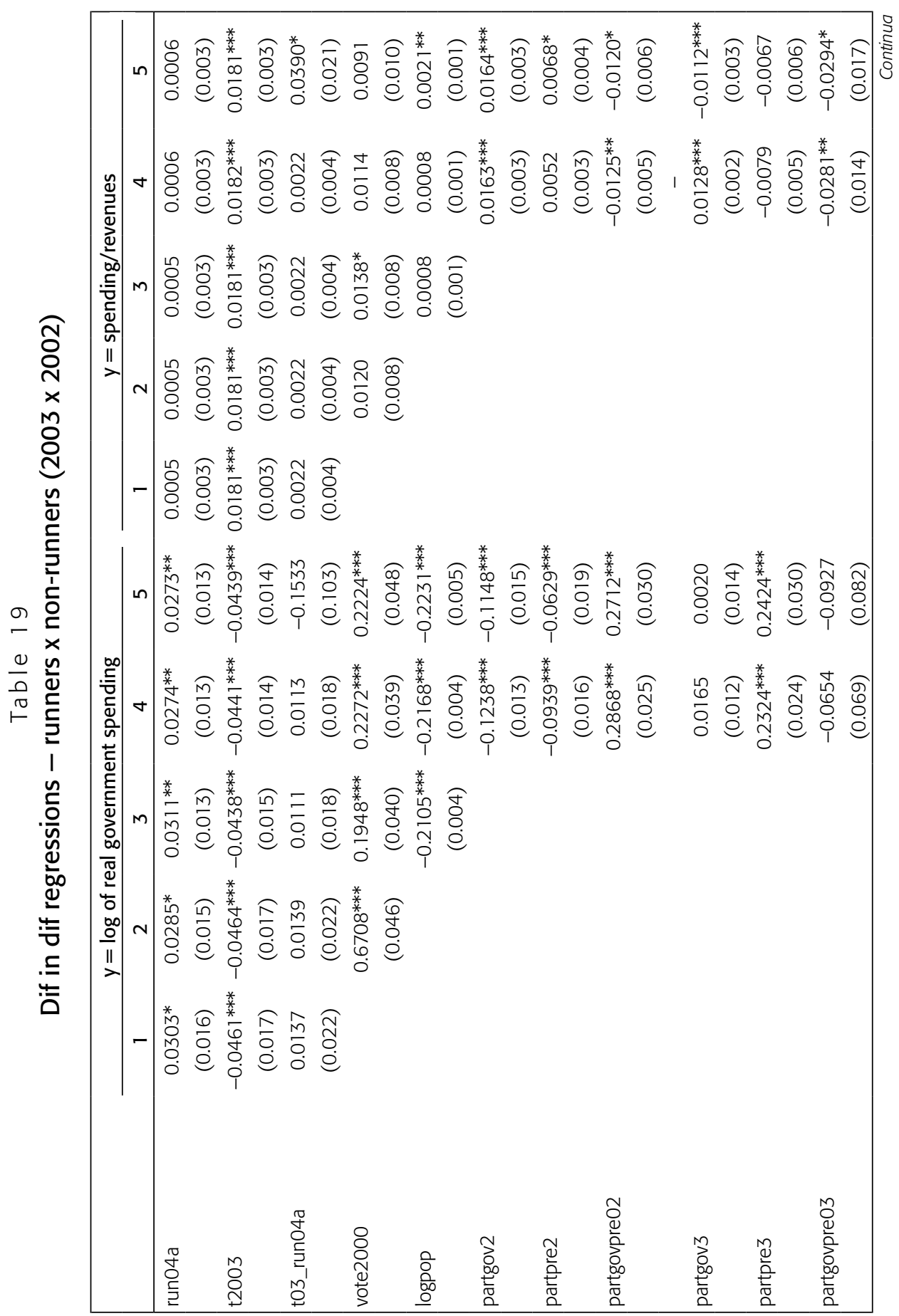




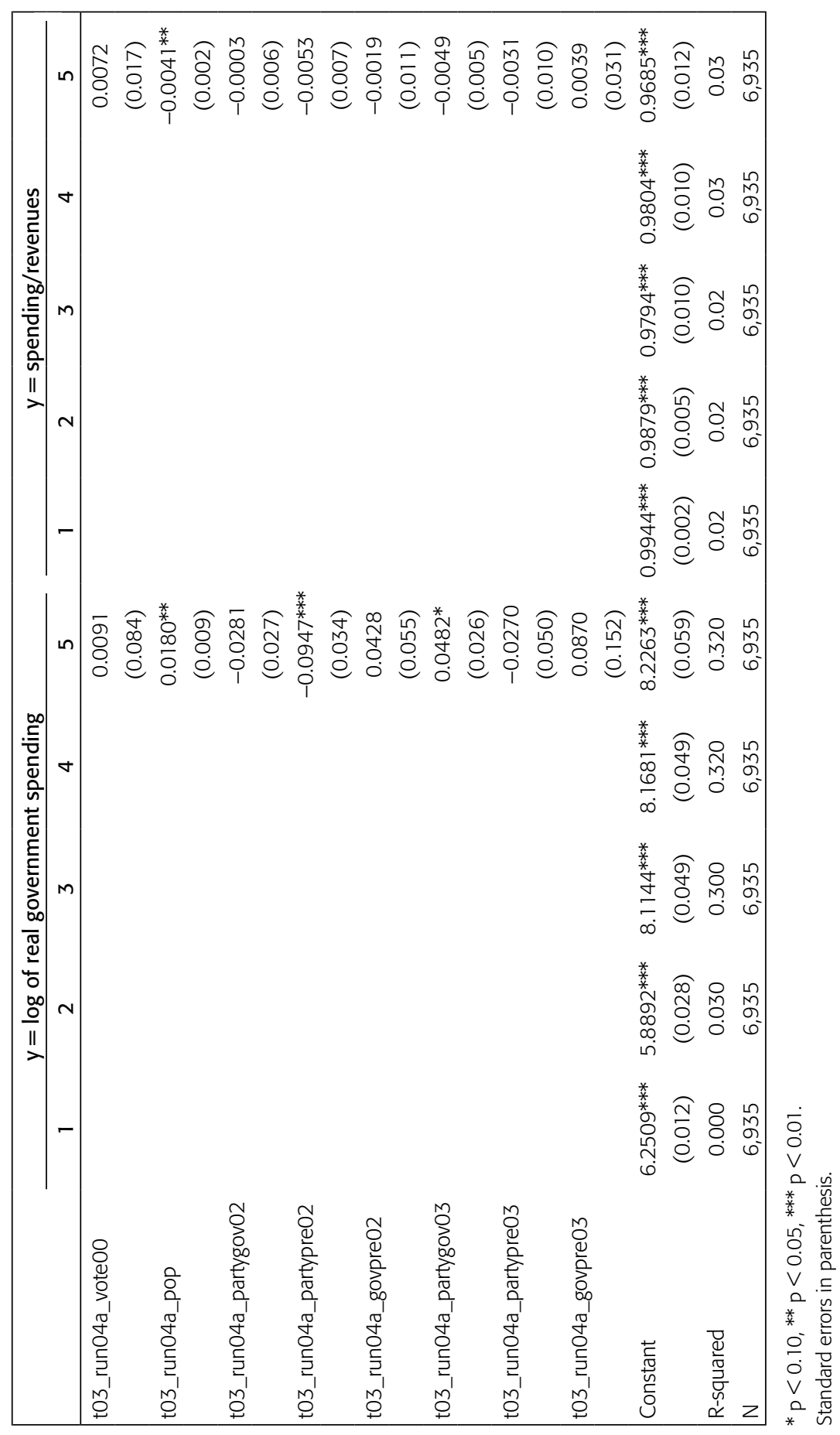


Comparing the reelection runners vs. non-reelectables group (tables 1215 ), the differences are a little stronger. From the tables, we see that the reelection runners' variation in government spending ranges from zero to $5 \% \mathrm{hi}$ gher than that of non-reelectables', while their deficit ratio ranges from $1.10 \%$ lower to $1.12 \%$ higher than the deficit ratio of the non-reelectables depending on the years used.

As for the reelection runners vs. non-runners group (tables 16-19), the former presents a variation in spending that ranges from zero to $4.8 \%$ higher than the variation of the later, while their deficit ratio ranges from zero to $1.5 \%$ higher than the figures for non-runners.

Based on these results, five comments are worth making. First, significant fiscal differences were observed mainly for the periods 2004 vs. 2001 and 2003 vs. 2001, when we should also expect differences for 2004 vs. 2002 and 2003 vs. 2002. As was already mentioned in the preceding section, the higher spending levels in 2002 followed by a contraction in 2003 most probably reflect the dynamics of a political budget cycle at the state and federal levels during the 2002 national elections, which might explain the increase in overall spending for this year, for example through higher state and federal transfers to municipalities. Depending on where and how such transfers occur, there might be political biases that are blurring the results. This was partially controlled for with the inclusion of party dummies reflecting the governors' and/or the President's party affiliation for 2002 and 2003, but they still did not explain much of the weak results for 2004 vs. 2002 and 2003 vs. 2002. The reason for including such dummies was that they could provide some hints as to whether the 2002 and 2003 municipal figures are affected by preelectoral (2002) and post-electoral (2003) funding and spending strategies at the state and/or federal levels.

Second, the political budget cycle phenomenon seems to be stronger for mayors who not only are eligible for reelection, but also and mostly for mayors who run for reelection, which explains why the treatment coefficients using run04 are usually higher than when reel is used. This somehow explains the weaker results reported in table 8. Because in this table the comparison is between reelectables and non-reelectables, it includes those mayors who are eligible for reelection, but choose not to run. This decision, whatever are the reasons behind it, probably reduces the incentives for a mayor to adopt the political budget cycle strategy, so that non-runners reelectables end up behaving as if they were non-reelectables.

Third, it seems that the political budget cycle is stronger when 2003 is considered the electoral year. This finding is aligned with the idea that there is a time-lag for spending to become visible to voters, and also seems to re- 
flect the restrictions of the Brazilian electoral legislation, which prohibits some types of expenditures 6 months before the elections. In other words, the PBC fully starts in the pre-electoral year 2003.

Fourth, as already discussed, the stronger results for 2004 vs. 2001 and 2003 vs. 2001 could be caused not by higher spending by the treatment group in the electoral years 2004 and 2003, but by lower spending in 2001 due to the technical and legal restrictions that new entrants commonly face. This could create the false idea that the treatment effect is positive even if the treatment and control groups had equal levels of spending in 2004 and 2003. But the results for the runners vs. non-runners group provide counterfactual evidence against this possibility, since both are new entrants and thus face the same problems regarding the first year of government; but still, runners present a higher variation in spending when compared to non-runners. This suggests that the decision to run for reelection is an important determinant of the political budget cycle.

Finally, reelectables and reelection runners present deficit ratios that are not substantially higher than those of non-reelectables and non-runners. Although they seem to spend relatively more in electoral years, they also seem to increase the revenues that are necessary to finance such spending, allowing them to avoid the undesirable deficits that could hurt their reelection chances.

The results provide an interesting estimate of the cost of the political budget cycle in the 2004 Brazilian municipal elections. From table 3 we know that non-reelectables have an average increase in real spending of $8 \%$ between 2004 and 2001, and that the average real government spending per capita in 2001 for the reelection runners is $\mathrm{R} \$ 538$. Since the econometric results indicate that runners have a variation which is $4.5 \%$ higher than that of non-reelectables between 2004 and 2001 (table 12), their total variation in spending would be close to $12.5 \%$ for this period, amounting to $R \$ 607$. This means that $8 \%$ would come from a natural budget cycle, which would be an increase of $\mathrm{R} \$$ $581-\mathrm{R} \$ 538=\mathrm{R} \$ 43$, and the other $4.5 \%$ would come from a political budget cycle, an increase of $R \$ 607-R \$ 581=R \$ 26$. This means that runners spend an additional $\mathrm{R} \$ 26$ in order to increase their reelection chances. This amount can be interpreted as the "price of vote". Taking into account that there were 2,243 Brazilian municipalities with mayors running for reelection in 2004, each having an average population of 29,275 citizens, this cost would amount to R $\$$ 1,707 billion (R $\$ 761,152$ by municipality). ${ }^{10}$ Generally speaking, we can say

\footnotetext{
${ }^{10}$ Under an exchange rate of R $\$ / \mathrm{US} \$=2.30$, the total amount is about US $\$ 742$ million dollars.
} 
that this amount is an estimate of the total cost of the political budget cycle in the 2004 municipal elections for mayors in Brazil.

Results for testing whether increased spending in electoral years result in higher probability of reelection as suggested in equation 5 are reported in tables 20 through 23, each corresponding to the variation in spending for the years 2004 vs. 2001,2004 vs. 2002, 2003 vs. 2001, and 2003 vs. 2002. From the tables, we see that mayors who have increased government spending in electoral years had greater chances of being reelected, even after controlling for the covariates. Note once more that the results are sensitive to the choice of years used as electoral and non-electoral ones, being significant and positive for the years 2004 vs. 2001 and 2003 vs. 2001 and not significant for the others. Again, this study suggests that the weak results for 2003 vs. 2002 and 2004 vs. 2002 is probably caused by the state and federal PBC caused by the 2002 national elections. The other significant variables are the share of votes in 2000 and the deficit ratios for 2003 and 2004. This shows that mayors seeking reelection increase their winning chances if they spend more in electoral years, but these chances decrease if they spend much beyond their available funds. The higher coefficients for the 2004 deficit ratio as opposed to that of 2003 is probably an indication of the limited capacity of voters of remembering past events as these get older.

Table 20

Logistic regressions on the probability of reelection $(2004 \times 2001)$

\begin{tabular}{|lcccccc|}
\hline $\mathrm{y}=$ reel04 & $\mathbf{1}$ & $\mathbf{2}$ & $\mathbf{3}$ & $\mathbf{4}$ & 5 & 6 \\
\hline varg41 & $1.1625^{* * *}$ & $1.1814^{* * *}$ & $1.1774^{* * *}$ & $1.1671^{* * *}$ & $1.6059^{* * *}$ & $2.1333^{* * *}$ \\
vote2000 & $(0.232)$ & $(0.236)$ & $(0.236)$ & $(0.237)$ & $(0.256)$ & $(0.554)$ \\
& & $2.9699^{* * *}$ & $2.8755^{* * *}$ & $2.9067^{* * *}$ & $2.7698^{* * *}$ & $2.7827^{* * *}$ \\
logpop04 & & $(0.434)$ & $(0.443)$ & $(0.446)$ & $(0.453)$ & $(0.454)$ \\
& & & -0.0405 & -0.0504 & $-0.0733^{*}$ & $-0.0698^{*}$ \\
partgov2 & & $(0.040)$ & $(0.041)$ & $(0.042)$ & $(0.042)$ \\
& & & & -0.0977 & -0.0539 & -0.053 \\
partpre2 & & & $(0.132)$ & $(0.135)$ & $(0.135)$ \\
& & & & 0.0225 & -0.0113 & -0.0156 \\
partgovpre02 & & & & $(0.163)$ & $(0.167)$ & $(0.167)$ \\
& & & & 0.3233 & 0.3469 & 0.355 \\
partgov3 & & & $(0.271)$ & $(0.275)$ & $(0.275)$ \\
& & & & 0.1263 & 0.0987 & 0.0994 \\
& & & & $(0.125)$ & $(0.129)$ & $(0.129)$ \\
\hline
\end{tabular}




\begin{tabular}{|lcccccc|}
\hline $\mathrm{y}=$ reel04 & 1 & 2 & 3 & 4 & 5 & 6 \\
\hline partpre3 & & & & $0.4192^{*}$ & 0.3534 & 0.3423 \\
partgovpre03 & & & & $(0.233)$ & $(0.237)$ & $(0.237)$ \\
& & & & -0.7588 & -0.8061 & -0.7627 \\
g/r2003 & & & & $(0.772)$ & $(0.779)$ & $(0.781)$ \\
& & & & & -0.962 & -0.8941 \\
g/r2004 & & & & & $(0.659)$ & $(0.662)$ \\
& & & & & $-5.1322^{* * *}$ & $-5.7979 * * *$ \\
varrev41 & & & & & $(0.747)$ & $(0.971)$ \\
& & & & & & -0.6198 \\
Constant & $0.2296 * * *$ & $-1.3709 * * *$ & $-0.9398^{*}$ & $-0.9082^{*}$ & $5.3276 * * *$ & $5.8759 * * *$ \\
& $(0.053)$ & $(0.238)$ & $(0.488)$ & $(0.493)$ & $(1.101)$ & $(1.214)$ \\
Log-Likelihood & -1435.53 & -1409.84 & -1409.33 & -1405.41 & -1356.76 & -1356.17 \\
Pseudo R-squared & 0.009 & 0.027 & 0.027 & 0.030 & 0.049 & 0.049 \\
$\mathrm{~N}$ & 2,145 & 2,145 & 2,145 & 2,145 & 2,112 & 2,112 \\
\hline
\end{tabular}

$* \mathrm{p}<0.10,{ }^{* *} \mathrm{p}<0.05,{ }^{* * *} \mathrm{p}<0.01$.

Standard errors in parenthesis.

Table 21

Logistic regressions on the probability of reelection (2004 x 2002)

\begin{tabular}{|lcccccc|}
\hline $\mathrm{y}=$ reel04 & $\mathbf{1}$ & $\mathbf{2}$ & $\mathbf{3}$ & $\mathbf{4}$ & 5 & 6 \\
\hline varg42 & 0.1143 & 0.149 & 0.1544 & 0.0809 & 0.4214 & 0.6603 \\
& $(0.274)$ & $(0.278)$ & $(0.278)$ & $(0.282)$ & $(0.311)$ & $(0.599)$ \\
vote2000 & & $2.9231^{* * *}$ & $2.8203^{* * *}$ & $2.8710^{* * *}$ & $2.7800^{* * *}$ & $2.7825^{* * *}$ \\
& & $(0.430)$ & $(0.440)$ & $(0.443)$ & $(0.448)$ & $(0.448)$ \\
logpop04 & & & -0.0444 & -0.0552 & $-0.0755^{*}$ & $-0.0742^{*}$ \\
& & & $(0.040)$ & $(0.041)$ & $(0.042)$ & $(0.042)$ \\
partgov2 & & & -0.134 & -0.0687 & -0.0671 \\
& & & & $(0.133)$ & $(0.135)$ & $(0.135)$ \\
partpre2 & & & 0.0221 & 0.0222 & 0.0233 \\
& & & & $(0.162)$ & $(0.165)$ & $(0.165)$ \\
partgovpre02 & & & 0.3166 & 0.2843 & 0.2824 \\
& & & & $0.270)$ & $(0.273)$ & $(0.273)$ \\
partgov3 & & & 0.1561 & 0.1197 & 0.1195 \\
& & & & $0.126)$ & $(0.128)$ & $(0.128)$ \\
partpre3 & & & $(0.234)$ & $(0.237)$ & $(0.237)$ \\
& & & & -0.6661 & -0.7099 & -0.711 \\
partgovpre03 & & & $(0.764)$ & $(0.765)$ & $(0.765)$ \\
\hline
\end{tabular}




\begin{tabular}{|lcccccc|}
\hline $\mathrm{y}=$ reel04 & $\mathbf{1}$ & $\mathbf{2}$ & $\mathbf{3}$ & $\mathbf{4}$ & 5 & 6 \\
\hline $\mathrm{g} / \mathrm{r}$ 2003 & & & & & $-1.1354^{*}$ & $-1.1266^{*}$ \\
& & & & & $(0.663)$ & $(0.664)$ \\
$\mathrm{g} / \mathrm{r}$ 2004 & & & & & $-3.6902^{* * *}$ & $-3.9523^{* * *}$ \\
& & & & & $(0.729)$ & $(0.921)$ \\
varrev42 & & & & & & -0.2853 \\
& & & & & & $(0.611)$ \\
Constant & $0.3576^{* * *}$ & $-1.2167^{* * *}$ & -0.7446 & -0.7172 & $4.2769^{* * *}$ & $4.5158^{* * *}$ \\
& $(0.045)$ & $(0.234)$ & $(0.485)$ & $(0.491)$ & $(1.083)$ & $(1.199)$ \\
Log-Likelihood & -1433.56 & -1408.31 & -1407.7 & -1403.04 & -1366.24 & -1366.13 \\
Pseudo R-squared & 0.000 & 0.018 & 0.018 & 0.021 & 0.032 & 0.033 \\
$\mathrm{~N}$ & 2117 & 2117 & 2117 & 2117 & 2085 & 2085 \\
\hline
\end{tabular}

* $p<0.10,{ }^{* *} p<0.05,{ }^{* * *} p<0.01$.

Standard errors in parenthesis.

Table 22

\section{Logistic regressions on the probability of reelection (2003 x 2001)}

\begin{tabular}{|c|c|c|c|c|c|c|}
\hline$y=$ reel04 & 1 & 2 & 3 & 4 & 5 & 6 \\
\hline varg31 & $\begin{array}{c}1.4599 * * * \\
(0.282)\end{array}$ & $\begin{array}{c}1.4775^{* * *} \\
(0.286)\end{array}$ & $\begin{array}{c}1.5647^{* * *} \\
(0.295)\end{array}$ & $\begin{array}{c}1.5656^{* * *} \\
(0.295)\end{array}$ & $\begin{array}{c}1.8589 * * * \\
(0.307)\end{array}$ & $\begin{array}{c}2.0670^{* * *} \\
(0.583)\end{array}$ \\
\hline vote2000 & & $\begin{array}{c}2.9224^{* * *} \\
(0.426)\end{array}$ & $\begin{array}{c}2.7554^{* * *} \\
(0.444)\end{array}$ & $\begin{array}{c}2.7941^{* * *} \\
(0.448)\end{array}$ & $\begin{array}{c}2.7965^{* * *} \\
(0.453)\end{array}$ & $\begin{array}{c}2.8010^{* * *} \\
(0.454)\end{array}$ \\
\hline logpop04 & & & $\begin{array}{r}-0.0611 \\
(0.040)\end{array}$ & $\begin{array}{c}-0.0715^{*} \\
(0.041)\end{array}$ & $\begin{array}{c}-0.0865^{* *} \\
(0.042)\end{array}$ & $\begin{array}{c}-0.0850^{* *} \\
(0.042)\end{array}$ \\
\hline partgov2 & & & & $\begin{array}{c}-0.11 \\
(0.133)\end{array}$ & $\begin{array}{c}-0.0601 \\
(0.135)\end{array}$ & $\begin{array}{c}-0.0604 \\
(0.135)\end{array}$ \\
\hline partpre2 & & & & $\begin{array}{l}0.0163 \\
(0.165)\end{array}$ & $\begin{array}{r}-0.0071 \\
(0.167)\end{array}$ & $\begin{array}{c}-0.0092 \\
(0.167)\end{array}$ \\
\hline partgovpre02 & & & & $\begin{array}{l}0.3236 \\
(0.272)\end{array}$ & $\begin{array}{l}0.3364 \\
(0.275)\end{array}$ & $\begin{array}{l}0.3405 \\
(0.275)\end{array}$ \\
\hline partgov3 & & & & $\begin{array}{l}0.1704 \\
(0.126)\end{array}$ & $\begin{array}{l}0.1056 \\
(0.129)\end{array}$ & $\begin{array}{l}0.1058 \\
(0.129)\end{array}$ \\
\hline partpre3 & & & & $\begin{array}{l}0.4453^{*} \\
(0.233)\end{array}$ & $\begin{array}{l}0.3814 \\
(0.236)\end{array}$ & $\begin{array}{l}0.3759 \\
(0.236)\end{array}$ \\
\hline partgovpre03 & & & & $\begin{array}{r}-0.6977 \\
(0.769)\end{array}$ & $\begin{array}{c}-0.7213 \\
(0.772)\end{array}$ & $\begin{array}{l}-0.703 \\
(0.774)\end{array}$ \\
\hline$g / r 2003$ & & & & & $\begin{array}{c}-2.2086^{* * *} \\
(0.671)\end{array}$ & $\begin{array}{c}-2.4205^{* * *} \\
(0.839)\end{array}$ \\
\hline$g / r 2004$ & & & & & $\begin{array}{c}-4.0216^{* * *} \\
(0.709)\end{array}$ & $\begin{array}{c}-4.0285^{* * *} \\
(0.709)\end{array}$ \\
\hline
\end{tabular}




\begin{tabular}{|lcccccc|}
\hline $\mathrm{y}=$ reel04 & $\mathbf{1}$ & $\mathbf{2}$ & $\mathbf{3}$ & $\mathbf{4}$ & 5 & 6 \\
\hline varrev31 & & & & & & -0.2769 \\
& & & & & & $(0.658)$ \\
Constant & $0.2337^{* * *}$ & $-1.3405^{* * *}$ & -0.6491 & -0.6271 & $5.6808^{* * *}$ & $5.8774^{* * *}$ \\
& $(0.048)$ & $(0.233)$ & $(0.491)$ & $(0.496)$ & $(1.105)$ & $(1.201)$ \\
Log-Likelihood & -1463.31 & -1437.62 & -1386.07 & -1381.53 & -1358.49 & -1358.4 \\
Pseudo R-squared & 0.010 & 0.027 & 0.028 & 0.032 & 0.048 & 0.048 \\
$\mathrm{~N}$ & 2,178 & 2,178 & 2,112 & 2,112 & 2,112 & 2,112 \\
\hline
\end{tabular}

$* \mathrm{p}<0.10,{ }^{* *} \mathrm{p}<0.05,{ }^{* * *} \mathrm{p}<0.01$.

Standard errors in parenthesis.

Table 23

Logistic regressions on the probability of reelection (2003 x 2002)

\begin{tabular}{|c|c|c|c|c|c|c|}
\hline$y=$ reel04 & 1 & 2 & 3 & 4 & 5 & 6 \\
\hline \multirow[t]{2}{*}{ varg32 } & -0.0481 & 0.0128 & -0.0282 & -0.1127 & 0.0369 & 0.466 \\
\hline & $(0.352)$ & $(0.356)$ & (0.369) & $(0.373)$ & (0.380) & (0.637) \\
\hline \multirow[t]{2}{*}{ vote2000 } & & $2.8533^{* * *}$ & $2.7383^{* * *}$ & $2.7944^{* * *}$ & $2.7851^{* * *}$ & $2.7906^{* * *}$ \\
\hline & & $(0.422)$ & $(0.441)$ & $(0.445)$ & $(0.448)$ & $(0.448)$ \\
\hline \multirow[t]{2}{*}{ logpop04 } & & & -0.0517 & -0.0625 & $-0.0747^{*}$ & $-0.0713^{*}$ \\
\hline & & & $(0.041)$ & $(0.041)$ & $(0.042)$ & $(0.042)$ \\
\hline \multirow[t]{2}{*}{ partgov2 } & & & & -0.1303 & -0.086 & -0.0853 \\
\hline & & & & (0.133) & $(0.135)$ & (0.135) \\
\hline \multirow[t]{2}{*}{ partpre2 } & & & & 0.0157 & 0.0068 & 0.0061 \\
\hline & & & & $(0.164)$ & $(0.165)$ & $(0.165)$ \\
\hline \multirow[t]{2}{*}{ partgovpre02 } & & & & 0.3066 & 0.3016 & 0.3019 \\
\hline & & & & $(0.271)$ & $(0.273)$ & $(0.273)$ \\
\hline \multirow[t]{2}{*}{ partgov3 } & & & & 0.182 & 0.1332 & 0.1334 \\
\hline & & & & $(0.126)$ & $(0.128)$ & $(0.128)$ \\
\hline \multirow[t]{2}{*}{ partpre3 } & & & & $0.5154^{* *}$ & $0.4507^{*}$ & $0.4505^{*}$ \\
\hline & & & & $(0.234)$ & $(0.236)$ & $(0.236)$ \\
\hline \multirow[t]{2}{*}{ partgovpre03 } & & & & -0.689 & -0.678 & -0.6804 \\
\hline & & & & $(0.764)$ & $(0.766)$ & $(0.767)$ \\
\hline \multirow[t]{2}{*}{ g/r2003 } & & & & & $-1.3173^{* *}$ & $-1.7679 * *$ \\
\hline & & & & & $(0.657)$ & (0.849) \\
\hline \multirow[t]{2}{*}{ g/r2004 } & & & & & $-3.4145^{* * *}$ & $-3.4045^{* * *}$ \\
\hline & & & & & (0.698) & (0.699) \\
\hline
\end{tabular}

Continua 


\begin{tabular}{|lcccccc|}
\hline $\mathrm{y}=$ reel04 & 1 & 2 & 3 & 4 & 5 & 6 \\
\hline varrev32 & & & & & & -0.5952 \\
& & & & & & $(0.709)$ \\
Constant & $0.3212^{* * *}$ & $-1.2137^{* * *}$ & -0.6298 & -0.6149 & $4.1925^{* * *}$ & $4.5882^{* * *}$ \\
& $(0.045)$ & $(0.230)$ & $(0.491)$ & $(0.496)$ & $(1.088)$ & $(1.187)$ \\
Log-Likelihood & -1464.03 & -1439.08 & -1387.15 & -1382.13 & -1367.17 & -1366.814 \\
Pseudo R-squared & 0.000 & 0.017 & 0.018 & 0.021 & 0.032 & 0.032 \\
$\mathrm{~N}$ & 2,152 & 2,152 & 2,085 & 2,085 & 2,085 & 2,085 \\
\hline
\end{tabular}

$* \mathrm{p}<0.10,{ }^{* *} \mathrm{p}<0.05, * * \mathrm{p}<0.01$.

Standard errors in parenthesis.

\section{Conclusions}

This article sought to verify the presence of political budget cycle (PBC) in municipal elections in Brazil and tried to answer whether mayors who adopt such policy have greater probability of reelection as opposed to those who do not. Based on a data comprising the elections for mayors in 5,406 Brazilian municipalities in 2004 and applying the difference-in-differences econometric method as well as logistic regressions, the results provide some evidence of PBC in Brazil, although its magnitude and consistency varies depending on the years used as electoral and non-electoral years. Additionally, the results suggest that mayors who increase public spending during electoral periods have greater chances of being reelected, as long as such spending is done within deficit limits acceptable by voters.

The results indicate that reelectables have a variation in government spending that ranges from zero to $3 \%$ higher than the variation in spending of non-reelectables, while reelection runners have a slightly higher figure, ranging from zero to $5 \%$ superior to that of non-reelectables and non-runners (reelectables who choose not to run). On average, runners spend an additional $\mathrm{R} \$ 26$ per capita in an election year if compared to non-reelectables. This amount can be interpreted as the "price of vote", as it should be the required increase in public spending if one wants to effectively increase his reelection chances. Taking into account that there were 2,243 Brazilian municipalities with mayors running for reelection in 2004, each having an average population of 29,275 citizens, this cost would amount to $\mathrm{R} \$ 1,707$ billion ( $\mathrm{R} \$ 761$ thousands per municipality), something around US\$ 742 million. Generally speaking, we can say that this amount is an estimate of the total cost of the political budget cycle in the 2004 municipal elections for mayors in Brazil. 
The results also show that reelectables and reelection runners are not necessarily less fiscally responsible than non-reelectables and non-runners, which is confirmed by their usually similar spending to revenues ratio. This happens because reelectables and reelection runners, although seem to spend relatively more in election years, also increase the revenues that are necessary to finance such spending, allowing them to avoid undesirable deficits that could hurt their reelection chances. Therefore, even though the literature suggests that the presence of a political budget cycle might harm the equilibrium of economic variables and of public finances, the results hereby presented indicate that this is not necessarily so. However, any analysis of political cycles based only on total spending loses part of the picture, because a political budget cycle might well occur merely through a change in the type of expenditures, leaving total spending unchanged (Eslava, 2005; 2006). Depending on how this change is done, there might be inefficient use of public funds. An obvious next step for the present study is to analyse whether reelectables and reelection runners are more prone to change spending from less visible public goods to more visible ones, such as roads, sewerage, hospitals, schools and electricity, as compared to non-reelectables and non-runners as elections get closer. The "change in composition" approach is even more justified in Brazil after the LRF was implemented in 2000, because its rules must have made it even more difficult for mayors to adopt the political budget cycle via an increase in total spending, even though they still seem to do so.

Another interesting finding is that the municipal PBC seems to be affected by state and federal electoral cycles, as indicated by the figures for 2002, an electoral year in Brazil for state governors, senators, federal deputies and the president. It seems possible that the characteristics of the Brazilian electoral system, which among other things intercalates state and federal elections with the municipal ones every two years, together with the permission of at most one reelection for executive posts, create an incentive for distinct disputes for budget resources throughout the elections cycle. For example, the observed increase in spending and revenues in 2002 possibly and partially caused by the state and federal elections rises the question as to whether the distribution and use of these resources are politically motivated, for example being conditioned to a mayor's party belonging or not to the state and/or federal party support group, to the mayor being eligible for reelection or not (or is running for reelection or not) and also to his or his party's real chances of being reelected. It could be that mayors whose parties belong to the support group of the state and/or federal government receive more transfers. This "party effect" could be intensified or diminished depending on whether the 
mayor is running for reelection and on his chances of being reelected. However, the dummy parties included in this study accounting for whether the mayor's party is the same as the governor's and/or the president's did not help much on answering this question.

If there is in fact such asymmetric dispute for budget resources during elections, it might well be enhanced in a context of federal decentralization and political fragmentation (e.g. coalition governments), as occurs in the Brazilian case, which together tend to promote an environment of fiscal indiscipline, making government spending to be above the optimal point of equilibrium (Eslava, 2006). In this sense, the implementation of fiscal and budgetary rules that restrict political interference, such as the LRF, seem welcomed. However, there is a trade-off between regulation and discretion: rules limit politically motivated deficits, but also create barriers for using them as anti-cyclical policy instruments for economic stabilization in times of adverse shocks (Corsetti and Roubini, 1997). Verifying the relation between political budget cycles, quality and effectiveness of public spending, federalism and the size of government seems to be a promising research agenda for answering these questions.

\section{References}

ALESINA, A. Macroeconomic policy in a two-party system as a repeated game. Quarterly Journal of Economics, n. 102, p. 651-678, 1987.

; ROUBINI, N. Political cycles in OECD economies. Review of Economic Studies, n. 59, p. 663-688, Oct. 1992.

BRENDER, A. The effect of fiscal performance on local government election results in Israel: 1989-1998. Journal of Public Economics, n. 87, p. 2187-2205, 2003.

; DRAZEN, A. Where does the political budget cycle really come from? Tel Aviv: Tel Aviv University, 2004. ms.

CORSETTI, G.; ROUBINI, N. Politically motivated fiscal deficits. Economics \& Politics, n. 9, p. 27-54, 1997.

DRAZEN, A.; ESLAVA, M. Political budget cycles without deficits: how to play favourites. College Park, MA: University of Maryland, 2004. ms.

evidence. NBER Working Paper n. 11085, 2005. 
ESLAVA, M. Political budget cycles or voters as fiscal conservatives? Evidence from Colombia. Bogotá: Centro de Estudios Sobre Desarrollo Economico, Universidad de los Andes. 2005. Edición electrónica.

. The political economy of fiscal policy: survey. Research Department, Interamerican Development Bank, 2006.

FRANZESE, R.; JUSKO, K. Political economic cycles. In: WEINGAST, B. R., WHITTMAN, D. A. (Eds.). Oxford handbook of political economy. Oxford: Oxford University Press, 2006.

HIBBS, D. Political parties and macroeconomic policy. American Political Science Review, v. 71, n. 4, p. 1467-1487, 1997.

LEE, M.-J. Micro-econometrics for policy, program, and treatment effects. New York: Oxford University Press, 2005.

LINDBECK, A. Stabilization policies in open economies with endogenous politicians. American Economic Review (Papers and Proceedings), n. 66, p. 1-19, 1976.

NORDHAUS, W. The political business cycle. Review of Economic Studies, v. 42, n. 1, p. 169-190, 1975.

PERSSON, T.; TABELLINI, G. Macroeconomic policy, credibility and politics. Newark, NJ: Harwood Academic Publishers, 1990.

PORTO, A.; PORTO, N. Fiscal decentralization and voter's choices as control. Journal of Applied Economics, v. 3, n. 1, p. 135-167, 2000.

ROGOFF, K. Equilibrium political budget cycles. American Economic Review, n. 80, p. 21-26, 1990.

; SIBERT, A. Elections and macroeconomic policy cycles. Review of Economic Studies, v. 55, n. 1, p. 1-16, 1988.

SCHUKNECHT, L. Political business cycles and expenditure policies in developing countries. IMF Working Paper n. 121, 1994.

SHI, M.; SEVENSSON, J. Political business cycles in developed and developing countries. The World Bank Working Paper, Feb. 2000. 